\title{
NATIONAL BUREAU OF STANDARDS REPORT
}

9426

SATURATING ORGANIC FELTS

by

Sidney H. Greenfeld

Research Associate

Asphalt Roofing Industry Bureau

Sponsored by

Asphalt Roofing Industry Bureau

\section{NBS}

U. S. DEPARTMENT OF COMMERCE NATIONAL BUREAU OF STANDARDS 


\section{THE NATIONAL BUREAU OF STANDARDS}

The National Bureau of Standards is a principal focal point in the Federal Government for assuring maximum application of the physical and engineering sciences to the advancement of technology in industry and commerce. Its responsibilities include development and maintenance of the national standards of measurement, and the provisions of means for making measurements consistent with those standards; determination of physical constants and properties of materials; development of methods for testing materials, mechanisms, and structures, and making such tests as may be necessary, particularly for government agencies; cooperation in the establishment of standard practices for incorporation in codes and specifications; advisory service to government agencies on scientific and technical problems; invention and development of devices to serve special needs of the Government; assistance to industry, business, and consumers in the development and acceptance of commercial standards and simplified trade practice recommendations; administration of programs in cooperation with United States business groups and standards organizations for the development of international standards of practice; and maintenance of a clearinghouse for the collection and dissemination of scientific, technical, and engineering information. The scope of the Bureau's activities is suggested in the following listing of its three Institutes and their organizational units.

Institute for Basic Standards. Applied Mathematics. Electricity. Metrology. Mechanics. Heat. Atomic Physics. Physical Chemistry. Laboratory Astrophysics." Radiation Physics. Radio Standards Laboratory:" Radio Standards Physics; Radio Standards Engineering. Office of Standard Reference Data.

Institute for Materials Research. Analytical Chemistry. Polymers. Metallurgy. Inorganic Materials. Reactor Radiations. Cryogenics." Materials Evaluation Laboratory. Office of Standard Reference Materials.

Institute for Applied Technology. Building Research. Information Technology. Performance Test Development. Electronic Instrumentation. Textile and Apparel Technology Center. Technical Analysis. Office of Weights and Measures. Office of Engineering Standards. Office of Invention and Innovation. Office of Technical Resources. Clearinghouse for Federal Scientific and Technical Information." "*

- Located at Boulder, Colorædo, 80301.

* Located at 5285 Port Royal Road, Springfield, Virginia, 22171. 
NATIONAL BUREAU OF STANDARDS REPORT

NBS PROJECT

$421.04-20-4212247$

NBS REPORT

9426
SATURATING ORGANIC FELTS

by

Sidney H. Greenfeld

Research Associate

Asphalt Roofing Industry Bureau
Sponsored by

Asphalt Roofing Industry Bureau

\section{IMPORTANT NOTICE}

NATIONAL BUREAU OF STA for use within the Government. B and review. For this reason, the whole or in part, is not authoriz Bureau of Standards, Washington the Report has been specifically $D$
Approved for public release by the Director of the National Institute of Standards and Technology (NIST) on October 9, 2015 accounting documents intended ibjected to additional evaluation isting of this Report, either in Office of the Director, National ie Government agency for which ies for its own use.

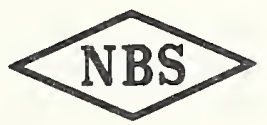

U. S. DEPARTMENT OF COMMERCE MATIONAL BUREAU OF STANDARDS 



\section{SATURATING ORGANIC FELTS}

\section{$\underline{\text { ABSTRACT }}$}

A study of the saturation of a 非7 felt with a typical roll saturant and a 非55 felt with roll, mixed and shingie saturants revealed that the degree of saturation varied with saturation time and pressure, saturant temperature and viscosity, felt conditions and press roll pressure and clearance. Optimum temperature and viscosity ranges were determined for each system. Both pressure and vacuum increased the degree of saturation under optimum conditions, but frequently shortened the working temperature range under which optimum saturation could be produced. Rate and degree of moisture and liquid water sorption decreased with increasing saturation. Alr permeability decreased with Increasing saturation. The consequences of some of these findings are discussed. 



\section{SATURATING ORGANIC FELTS}

\section{Sidney H. Greenfeld}

\section{INTRODUCTION}

The function of a roofing felt is to supply a strong backing for a weather-resistant asphalt coating. When used in the manufacture of prepared roofing, the felt permits the product to be cut into appropriate designs, packaged, handled and applied without distortion. When used in built-up roofing, it serves to isolate the several layers of waterproofing and provides the strength necessary for large areas of roofing to cope with the environmental stresses to which they are subjected. In order for the felts to function properly, they must be protected both externally and internally, for the felts themselves are vulnerable to the weather.

The external protection is provided by the coating applied to both the weather side and back of the roofing. This coating will not be discussed.

The internal protection is provided by a light bituminous saturant applied through a series of dips, or sprays and dips, as described by Abraham (1) ${ }^{\text {a }}$ and Krchma (2). Complete saturation is very difficult to achieve commercially, for modern roofing machines operate at 250 to 500 feet per minute and frequently allow times of less than one minute for saturation to occur. During this time, the felt, usually at room temperature with five to seven percent free moisture, must be heated to

a/ The numbers in parentheses refer to the references at the end of this report. 

saturant temperature, desiccated and saturated. The final stages of saturation actually occur beyond the saturant baths, where the excess saturant on the felt surfaces is drawn into the felt as it cools.

The saturant in the vicinity of the felt is cooled as the felt is heated and the moisture evaporated. Thus, its increased viscosity at this lower temperature tends to slow the penetration of the saturant into the felt. This cooling effect b/ also makes it possible for the felt to carry more saturant with it from the saturator. Thus, optimum conditions must be found for particular felt-saturant systems.

While, in principle, it is desirable to protect the felt by saturating it as completely as possible, problems of adhesion of coating to felt in shingles and roll roofing may result if a large excess of saturant is permitted to remain on the felt surface. Compatibility and coating slippage problems (through thinning of the coating) are aggrevated by this excess saturant. In the case of saturated felts, sticking in storage under over-saturated conditions is possible. Thus, when specifications are written, compromise saturations are required.

b/ A typical saturator running at $400 \mathrm{ft}$ per min would saturate 12 squares of felt per min. At six percent moisture content, about 15,000 Btu per min would be required to heat the felt and evaporate the moisture. This quantity of heat, if supplied entirely by the saturant used in saturating those 12 squares of felt, would lower the saturant temperature about $135^{\circ} \mathrm{F}$. In practice, there is agitation in the saturator and heat is supplied by saturant other than that which actually enters the felt; however, all of this heat must be furnished by heating the saturant to temperatures in excess of the optimum. 

In shingles, 170 percent saturation; that is, saturant weighing 1.70 times as much as the dry felt, is the minimum permitted. For roll roofing this minimum is dropped to 160 percent and for saturated felt, it is dropped further to 140 percent. These figures are the compromises made to ascommodate production, storage and application requirements. Theoretically, completely impregnated felt can hold about 235 percent $^{\text {c }}$ of 1 ts weight in saturant. Asphalt saturating numbers $\frac{d}{\text { a }}$ at about 210 percent by the vacuum method and 195 percent by the burette method may be more realistic values to try to attain commercially.

Contemporary commercial saturating techniques produce fel.ts meeting the specifications and exceeding them only by small margins. Improved techniques could lead to tighter specifications and better internally protected felts.

Based on these considerations, a study was undertaken to investigate the felt-saturating process and determine the effects of temperature, pressure, moisture, time and saturant on the saturating of organic felts.

c/ On the assumption that the felt is crystalline cellulose with a specific gravity of 1.53 (3), the ratio of space to cellulose in felt is 2.35. If felt is assumed to be similar to cotton linters, true density values of $1.55-1.61$ would have to be used (4) and a somewhat higher theoretical porosity obtained.

d/ The asphalt saturating number is the kerosene number multiplied by the ratio of the specific gravity of the asphalt saturant to that of the kerosene. 



\section{MATERIALS}

\section{(a) Felts}

Two grades of commercial felt were supplied by the Ruberold Company. These were taken from the normal production at their Gloucester City, New Jersey, mill and slit into 12-inch rolls for this project. These felts had the characteristics reported in Table I.

TABLE I

\section{Felt Characteristics}

\begin{tabular}{|c|c|c|c|}
\hline \multicolumn{2}{|c|}{ Grade Number } & 27 & 55 \\
\hline \multicolumn{2}{|c|}{ Dry Weight, Ib/480 $\mathrm{ft}^{2}$} & 27 & 53 \\
\hline \multicolumn{2}{|c|}{ Caliper, mils } & 33 & 64 \\
\hline \multicolumn{4}{|c|}{ Tens1le Strength, Machine } \\
\hline \multicolumn{4}{|c|}{ Tens1le Strength,Cross } \\
\hline \multicolumn{2}{|c|}{ Densometer, seconds/400 cc } & $18(16.2 *)$ & $18(18.3 *)$ \\
\hline \multicolumn{2}{|c|}{ Asphalt Saturating Number } & $183 * *(177 *)$ & $197 * *(187 *)$ \\
\hline \multicolumn{2}{|c|}{ Moisture (as received), \% } & 4.1 & 4.1 \\
\hline$*$ & Determined at NBS. & & \\
\hline 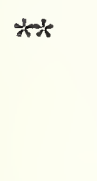 & $\begin{array}{l}\text { These numbers are based } \\
\text { the saturant. When con } \\
\text { gravity of unity, as us } \\
\text { become } 177 \text { (非 } 27 \text { felt) a }\end{array}$ & $\begin{array}{l}\text { a specific gra } \\
\text { ted for a satur } \\
\text { in this program } \\
190 \text { (非55 felt). }\end{array}$ & $\begin{array}{l}y \text { of } 1.035 \text { for } \\
\text { of specific } \\
\text { hese figures }\end{array}$ \\
\hline
\end{tabular}



The felt furnish was not supplied; the ratios of wood fibers, rags and paper are continually being adjusted during production to keep the felt properties unfform. Oak and pine flbers were used along with No. I waste paper and rags.

\section{(b) Saturants}

Two saturants were provided by the Mob11 011 Company from their Kansas refinery. These consisted of a soft, roll saturant and a hard, shingle saturant. These two were blended to produce a third saturant, termed a "mixed" saturant. The properties of these three materlals are Iisted In Table II.

\section{TABLE II}

\section{Properties of Saturants}

\begin{tabular}{|c|c|c|c|}
\hline Saturant & RolI & Shingle & Mixed \\
\hline Softening Point, ${ }^{\circ} \mathrm{F}$ & 111 & 141 & 125 \\
\hline Penetration at $77^{\circ} \mathrm{F}, 1 / 10 \mathrm{~mm}$ & 139 & 48 & 81 \\
\hline Penetration at $32^{\circ} \mathrm{F}, 1 / 10 \mathrm{~mm}$ & - & 18 & 23 \\
\hline Specific Gravity, $77 / 77^{\circ} \mathrm{F}$ & 0.9954 & 1.0002 & - \\
\hline Flash Point $(c . o . c),.{ }^{\circ} \mathrm{F}$ & 630 & 625 & 625 \\
\hline Loss on Heating & 0 & 0 & 0 \\
\hline Solubility in $\mathrm{CCl}_{4}, \%$ & 99.4 & 99.4 & 99.4 \\
\hline
\end{tabular}

The viscosity-temperature relations are presented in Figure 1. 



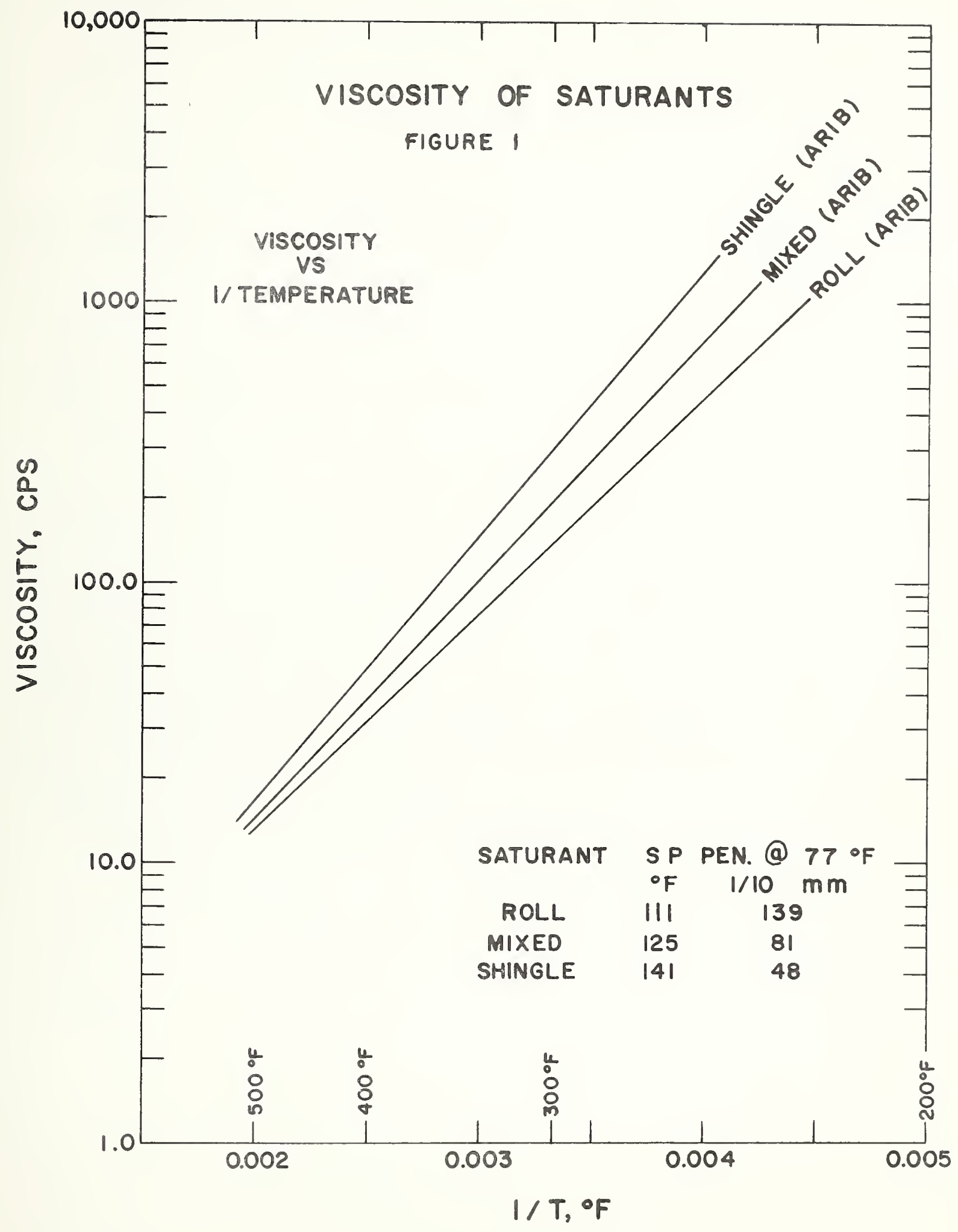





\section{APPARATUS}

Three apparati were used in this study. For all specimens saturated at atmospheric pressure, the apparatus shown in Figure 2 was used. For those saturated under vacuum or pressure, the apparati in Figures 3 and 4, respectively, were used.

The apparatus used for saturating at atmospheric pressure consisted of a stalnless-steel saturant pan $7^{\prime \prime} \times 9^{\prime \prime} \times 2^{\prime \prime}(18 \times 23 \times 5 \mathrm{~cm})$ and press rolls. The pan was heated on a thermostated hot plate capable of temperatures up to $600^{\circ} \mathrm{F}\left(316^{\circ} \mathrm{C}\right)$. Once the specimens were saturated, they were passed through the heated, manually operated rolls shown to the left in Figure 2. These rolls were provided with pressure adjustments to permit pressures resulting from the weight of the roll and higher. For most of the saturations, the weight of the upper roll was the sole source of pressure. However, in one serles of saturations, spacers consisting of multiple layers of 5-ml thick aluminum tape were used to permit controlled excesses of saturant to be carried on the felt. A thermostated air oven was used to maintain the saturated specimens at elevated temperatures $\left(250^{\circ}\right.$ or $\left.350^{\circ} \mathrm{F}\right)\left(121^{\circ}\right.$ or $\left.177^{\circ} \mathrm{C}\right)$ for a period of time to simulate the soaking-in period between saturation and coating in commercial operation. A similar oven, maintained at $225^{\circ} \mathrm{F}\left(107^{\circ} \mathrm{C}\right)$ was used to dry the felt prior to saturation (when desired). 



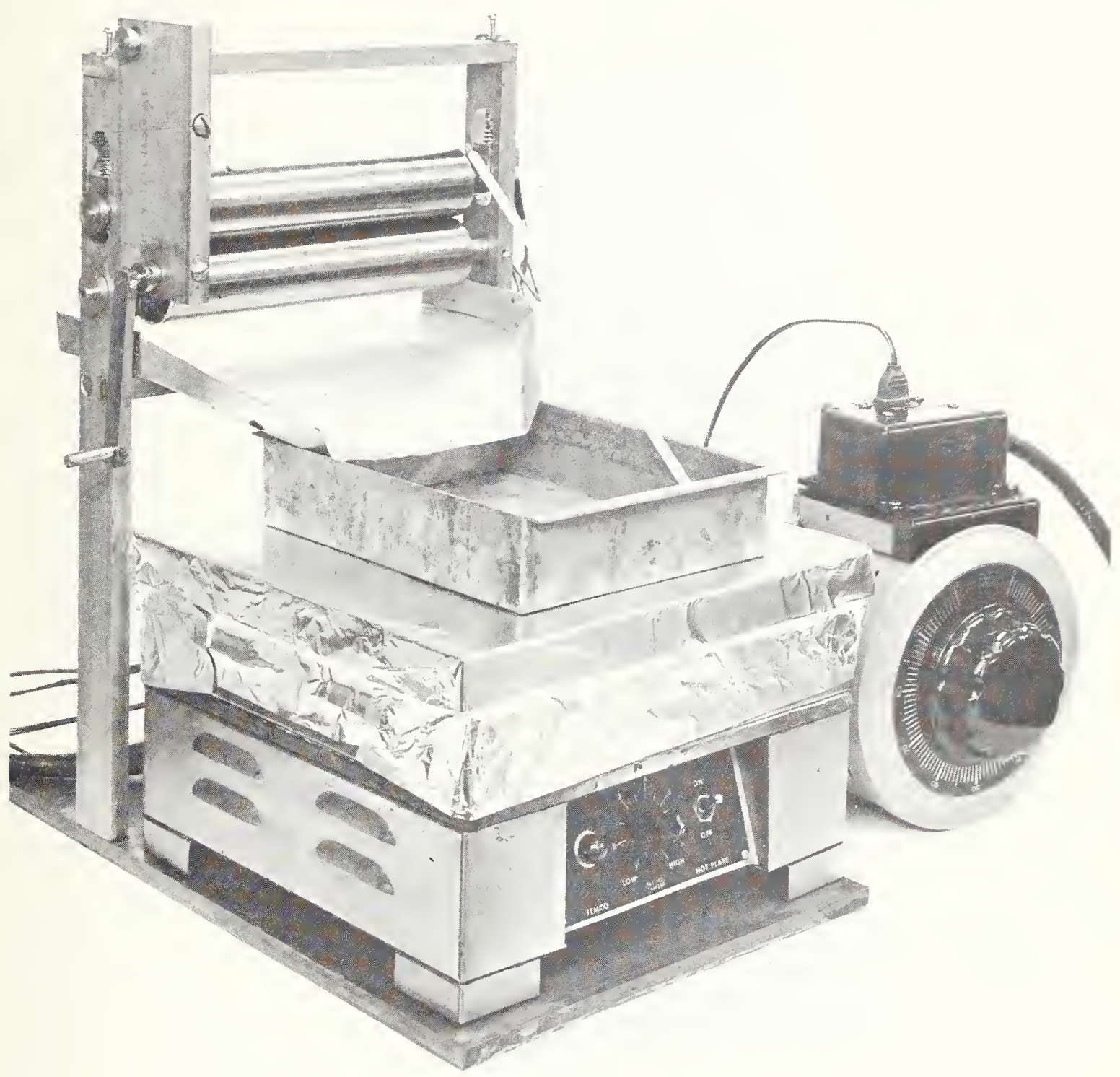

Figure 2 



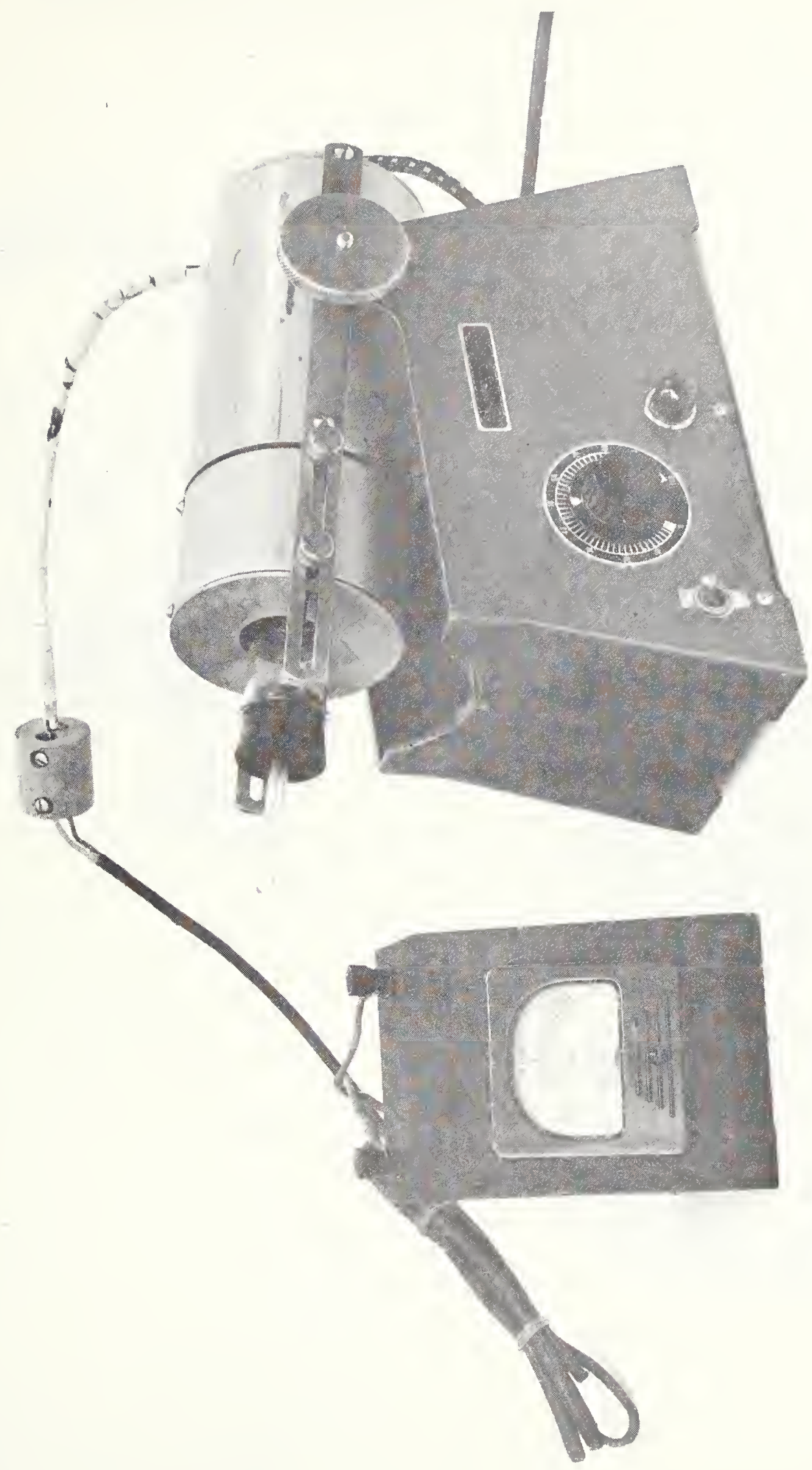

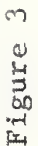





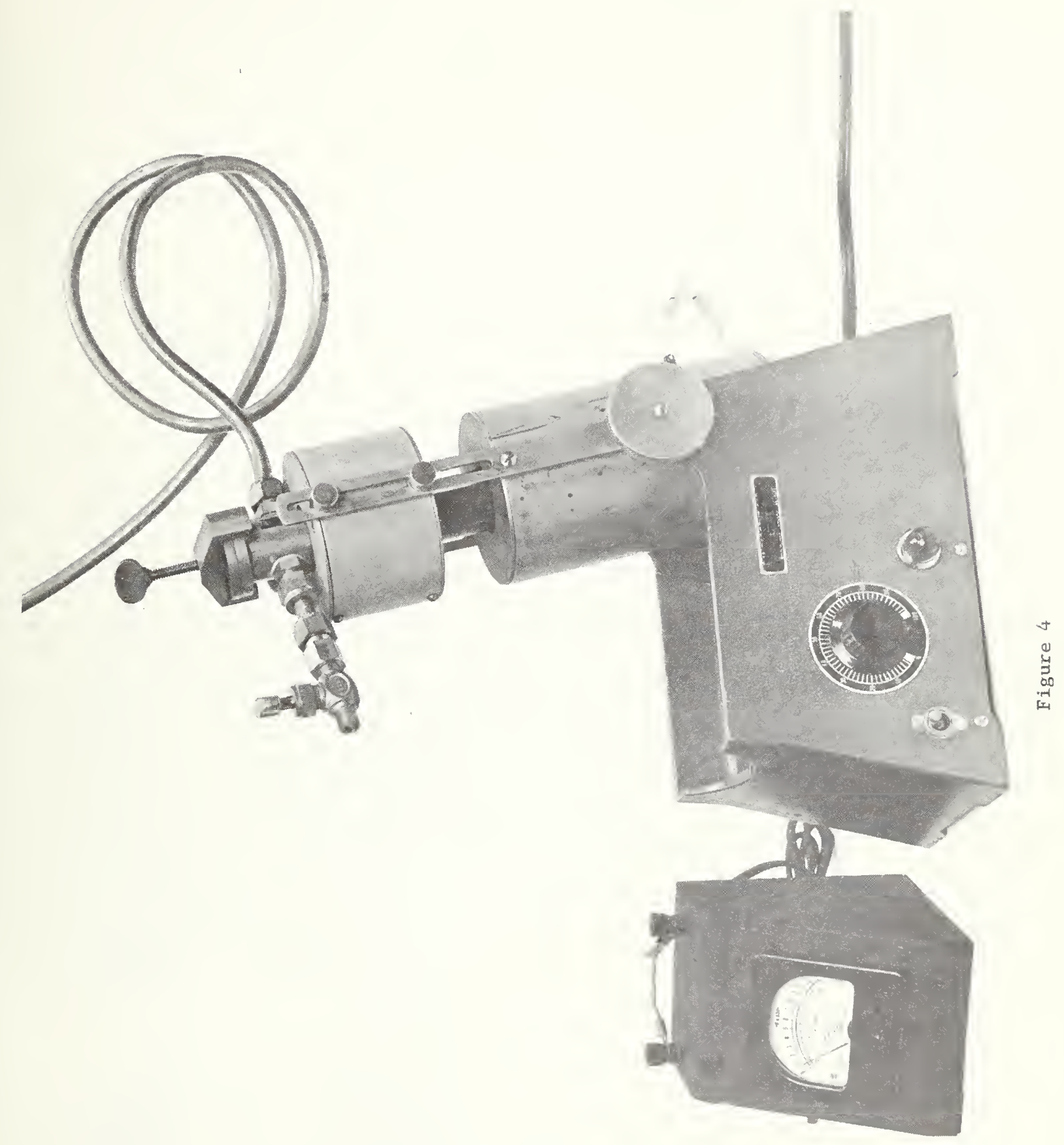



Whereas $6-\times 8$-inch $(15 \times 20 \mathrm{~cm})$ felt specimens were normally saturated, under both vacuum and elevated pressures 1 - $\times 2.5$-inch $(2.5 \times 6.4 \mathrm{~cm})$ specimens were used. The saturator (Figure 3) in the vacuum studies was a $32-\mathrm{x} 200-\mathrm{mm}$ test tube heated in an aluminum block furnace. Vacuum was applied by a water aspirator and measured with a mercury manometer. The same furnace was used to heat a brass pressure vessel for the super-atmospheric pressure saturations, as shown in Figure 4. Dry nitrogen was used to produce the pressure.

\section{PROCEDURES}

The procedures followed while saturating felts at ambient pressure, under vacuum and at super-atmospheric pressure were different and, therefore, will be described separately. Every day, while the saturant was being heated, moisture determinations were made on two representative samples of felt. It was found that both the 非 27 and 非55 felts required at least 45 minutes in an oven at $225^{\circ} \mathrm{F}\left(106^{\circ} \mathrm{C}\right)$ to be dried to constant weight. Therefore, the felts were heated in the oven for one hour and weighed immediately, for even in a desiccator the felts were found to sorb moisture. The average of the two moisture determinations was used in calculating the percent saturation of the felts. 

When the saturant in the pan was at the desired temperature and the pressure rolls were at $240 \pm 10^{\circ} \mathrm{F}\left(116^{\circ} \pm 6^{\circ} \mathrm{C}\right)$, a $6-\times 8$-inch $(15 \times 20 \mathrm{~cm})$ piece of felt was floated on the saturant for one and a half minutes, submerged for two minutes, passed once through the rolls, hung in the "soaking-in" oven at $250^{\circ} \mathrm{F}\left(121^{\circ} \mathrm{C}\right)$ for five minutes, and then weighed. This procedure was arbitrarily adopted because it required about one and a half minutes for the saturant to strike through the floating felt at $400^{\circ} \mathrm{F}\left(204^{\circ} \mathrm{C}\right)$ and it required about two minutes of complete submergence for the bubbling of gases and vapors from the felt to stop. Later in the work it was found that, with the two-minute-submergence time, saturation was independent of float time and, therefore, the float time was eliminated. At about the same time, the Research Committee reported that the "soaking-in" period occurred commercially at temperatures more nearly $350^{\circ} \mathrm{F}\left(177^{\circ} \mathrm{C}\right)$ than the $250^{\circ} \mathrm{F}\left(121^{\circ} \mathrm{C}\right)$ being used. This higher temperature seemed to reduce the number of felts rejected for "wetness" on their surfaces, but had no effect on the quantity of saturant remaining in the acceptable felts. Thus, the figures reported were not influenced appreciably by these changes. 

In the vacuum series of saturations, the saturant was heated in the test tube as shown in Figure 3. The felt was placed in the test tube above the saturant with the furnace inclined about $30^{\circ}$. The tube was evacuated. The furnace was rotated to a vertical position to permit the felt to submerge in the saturant. After the periods of time of submergence reported, the vacuum was broken, the specimen passed once through the rolls in the atmospheric-pressure apparatus and soaked in the oven for five minutes at $250^{\circ} \mathrm{F}\left(121^{\circ} \mathrm{C}\right)$. Any excess saturant on the edges of these specimens was wiped off prior to final weighing, for this material was sufficient to ralse the saturations reported for these small spectmens.

When saturating under pressure, the $1-\times 2.5$-inch $(2.5 \times 6.4 \mathrm{~cm})$ specimen was dropped directly into the saturant when the latter was at the desired temperature. The cover was fastened in place and the pressure raised rapidly to the desired level. After the desired time had elapsed, the pressure was released, the specimen passed through the heated rolls of the apparatus in Figure 2, and hung in the oven for five minutes at $350^{\circ} \mathrm{F}\left(177^{\circ} \mathrm{C}\right)$. Excess saturant was wiped from the edges immediately prior to weighing. 



\section{RESULTS AND DISCUSSION}

The saturating of organic felts is affected by many varlables, some of which are within the scope of this program and some not. Those involved in the furnish and production of the felt, or in the production of saturants, will not be considered; some of those relating to the saturant and the actual contact between the felt and the saturant will be discussed.

\section{(a) Contact IIme}

Large volumes of inert gases and vapors are released from organic felts when contacted with hot saturants. These expand and escape from the felt as the saturant penetrates and tries to saturate it. There is obviously a conflict between these processes during saturation. A number of methods have been devised to cope with this problem. The most common procedure has been wetting the felt from one side, either by spraying hot saturant on it or by contacting the saturant on one side only, and permitting the gases and volatiles to escape from the other side. This approach was simulated by floating the felt on the asphalt saturant surface prior to complete immersion. In Figure 5 are the results of various times of floating prior to complete submersion for one or two minutes and various times of submersion with no float time for both the 非 27 and 非5 felts. For the 非 27 felt, which is only about 30 mils thick, the method of processing had only a very limited effect on the degree of saturation; the percent saturation was essentially independent of the procedure. There is, however, a small, but consistent decrease in saturation with longer periods of exposure of the felts to 



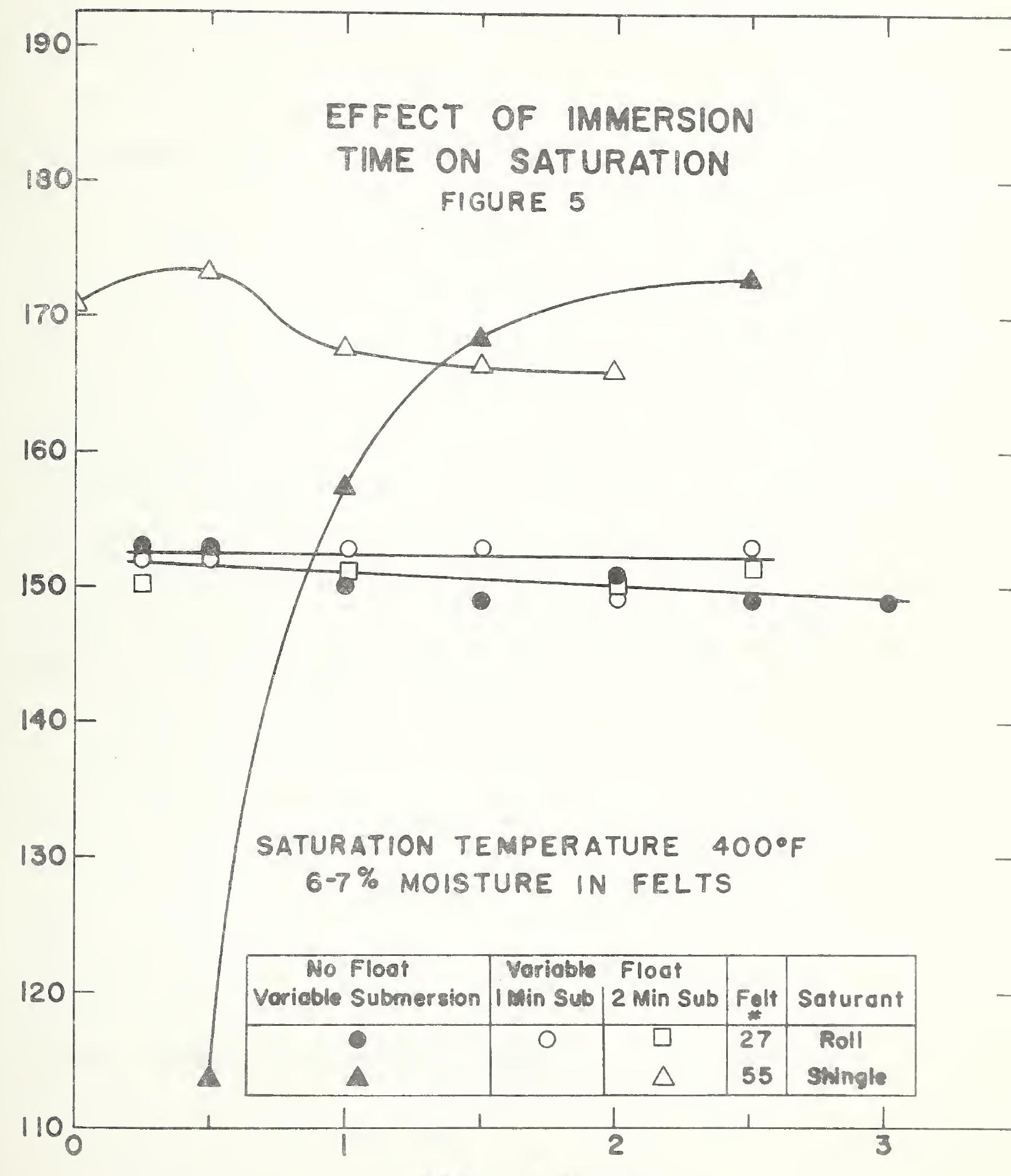

TIME, MINUTES 

the high temperature of the saturants. It is quite apparent that contact times between the 非 27 felts and saturants of more than a half-minute are adequate to produce saturations in excess of those required by current specifications ( 140 percent minimum).

Saturation of the 非5 felts, on the other hand, was sensitive to the means by which the felt was saturated. When the felts were submerged without previous floating, the saturation increased progressively with time of submersion up to about two minutes; however, beyond about one and a half minutes, saturation was essentially independent of submersion time. When float time was followed by two minutes of submersion, the shorter float times produced the highest saturations. However, the results were essentially constant after one minute of float time. Long submersion times were detrimental to the percent saturation. Based on these results, floating was eliminated and two minutes of submersion became the standard practice. This practice produced saturations of about 170 percent for the 非55 felt and 150 percent for the 非 27 felt at $400^{\circ} \mathrm{F}$; both would meet current specifications.

(b) Moisture and Temperature

The roofing manufacturex usually has little control over the moisture content of the dry felt, for it varies widely with the relative humidity of the atmosphere in which the felt is stored. The data presented in Figure 6 show how rapidly the felts sorb moisture from the atmosphere when exposed to relative humidities in the range of 30 to 75 percent. At higher relative humidities, the moisture content of the felts increases rapidly. At room temperature and 78 percent relative humidity 



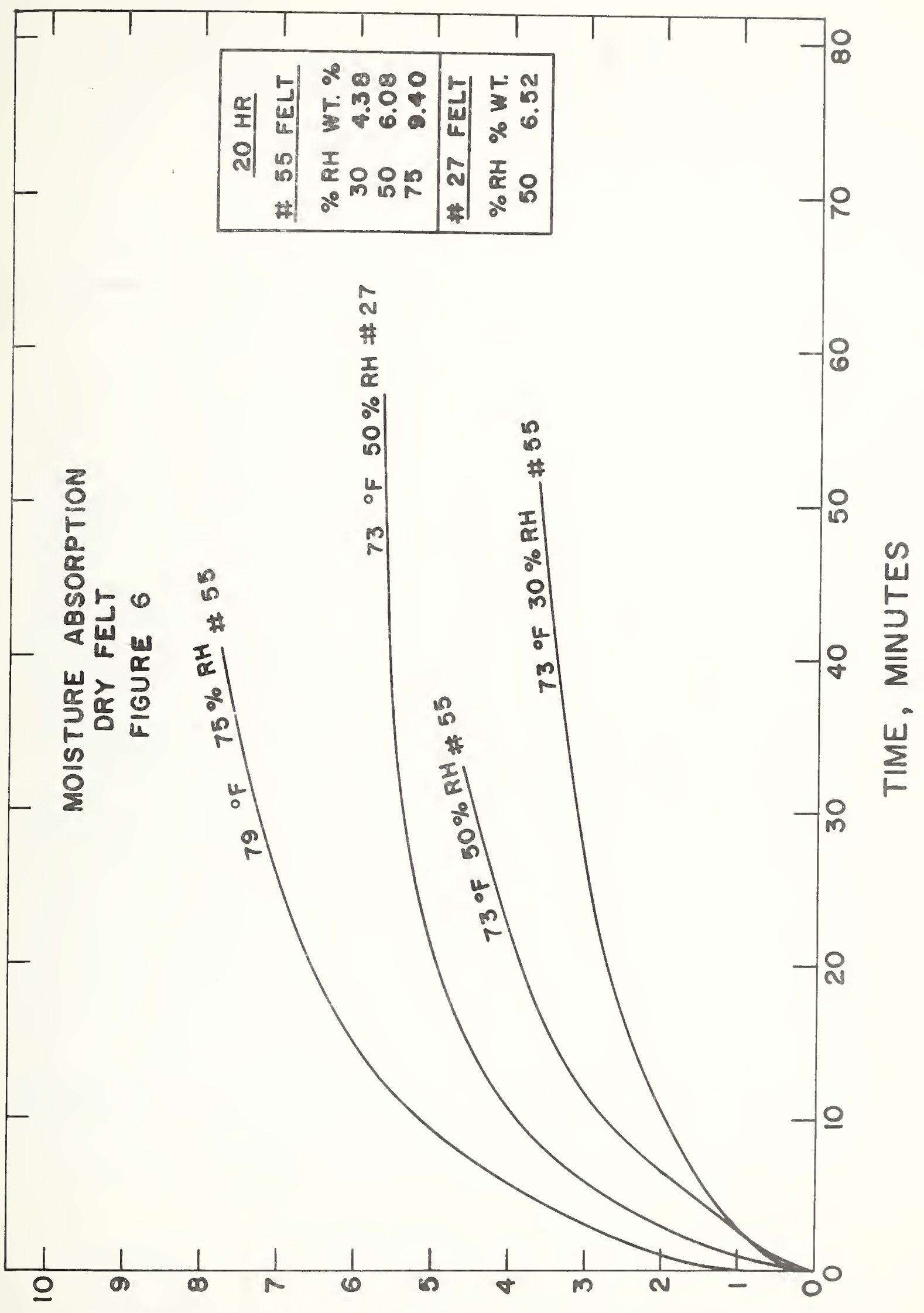

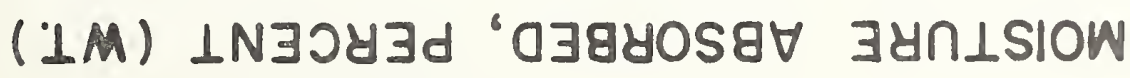



(saturated sodium hyposulfite solution), the equilibrium moisture content of these felts is about 12 percent ef and in a saturated atmosphere it is between 32 and 33 percent.

During the saturating process the moisture in the felt must be eliminated. In the process of being volatized, it absorbs large quantities of heat. As it escapes, it slows the penetration of the saturant into the felt. However, moisture in the felt serves two beneficial purposes. Felt with moisture contents below about three percent are very brittle. They frequently tear in the saturating process and require patching of the felt or rethreading of the machine. Thus, for continuous operation a minimum of three percent moisture is necessary. Moisture also lubricates the fibers or fiber bundles to permit their movement over each other and swells the fibers to permit the saturant to penetrate them more easily. However, when the moisture content is too high, the felts again become weak and breaks occur. In order for relative humidity changes to affect felts rapidly, there must be intimate contact between the atmosphere and the felts. Because felts are stored in large rolls, only their edges are affected by short-term changes in relative humidity. (Some edge curling might be attributed to this effect). The interior of the rolls of felt remain essentially as they were when rolled, except after long-term storage under extreme humidity conditions.

e/ Moisture content is expressed on an "oven dry" basis rather than an. "as received" basis. 

The moisture content of the felt is not very readily controllable; the temperature of the saturant is. Through heating the saturant and agitating it, in the saturators, fairly good temperature control can be attained. The data presented in Flgure 7 are of the variation in the saturant content of the 非 7 felt with the viscosity of the saturant for three conditions of the dry felt There was little difference between felt that was oven dry and cooled to room temperature in a desiccator and that which was saturated as it was removed from the drying oven. However, the felt with seven percent moisture absorbed three to seven percent more saturant in the normal saturating range. At the lowest temperatures at which saturation was successful with these materials, the moisture content was relatively unimportant, for a heavy film of saturant remained on the surface of the felt and soaked in during the period in the oven. At the higher temperatures, the saturant was very fluid and in an "expanded" state; the felt could not carry enough saturant to meet specifications at temperatures above $400^{\circ} \mathrm{F}\left(205^{\circ} \mathrm{C}\right)$ with seven percent moisture or above $350^{\circ}-375^{\circ} \mathrm{F}\left(175^{\circ}-190^{\circ} \mathrm{C}\right)$ when dry.

For the 非55 felt, (Figure 8) some moisture was necessary to permit sufficient saturation with the shingle saturant to meet the ASTM specification of 170 percent (ASTM D 225-65). Neither dry felt, cold or warm, could be saturated beyond 165 percent. In addition, the saturant did not penetrate well at temperatures below $3250 \mathrm{~F}\left(163^{\circ} \mathrm{C}\right)$ (about $180 \mathrm{cps}$ ), when dry felt was used. With seven percent moisture, 



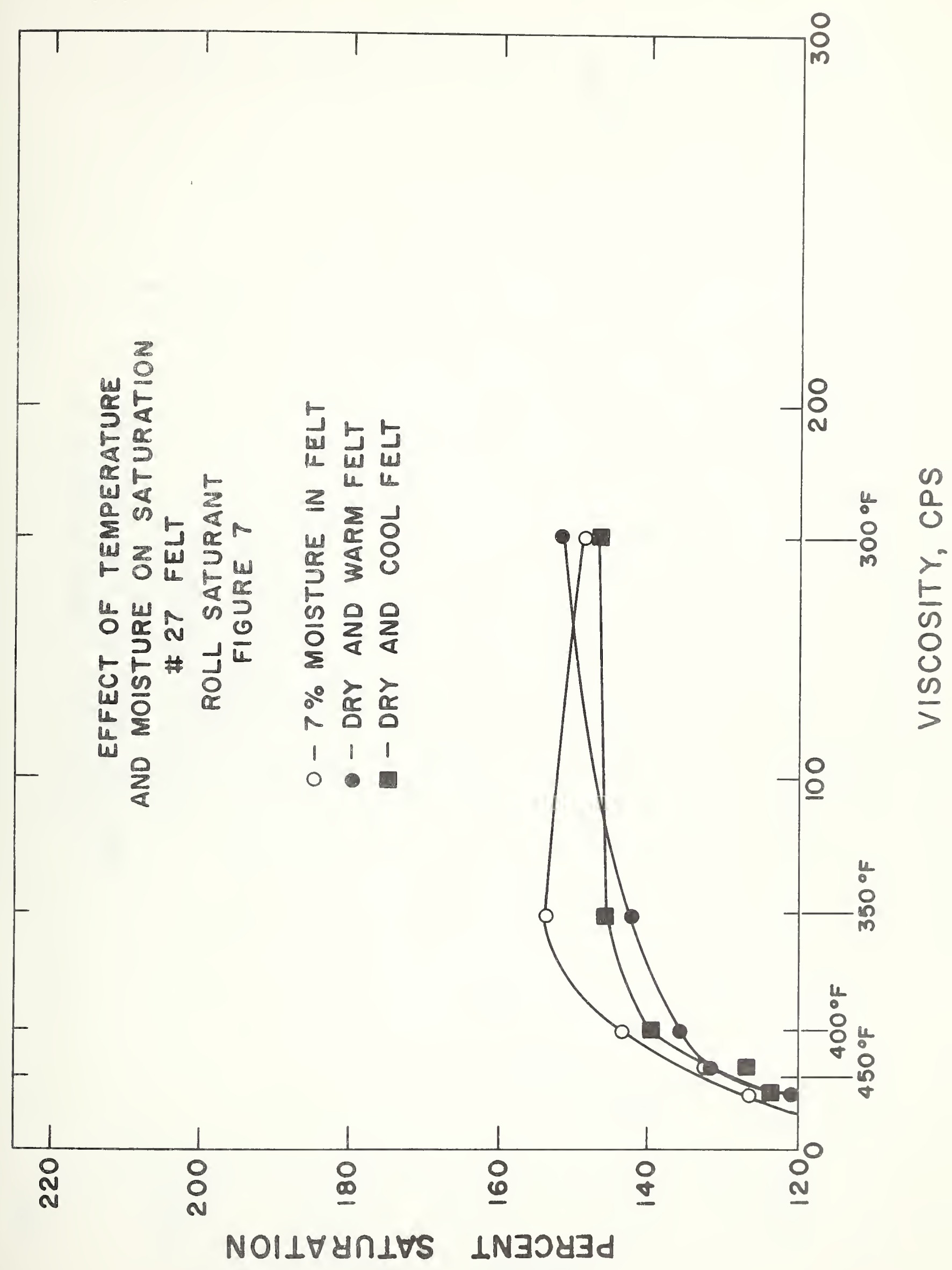





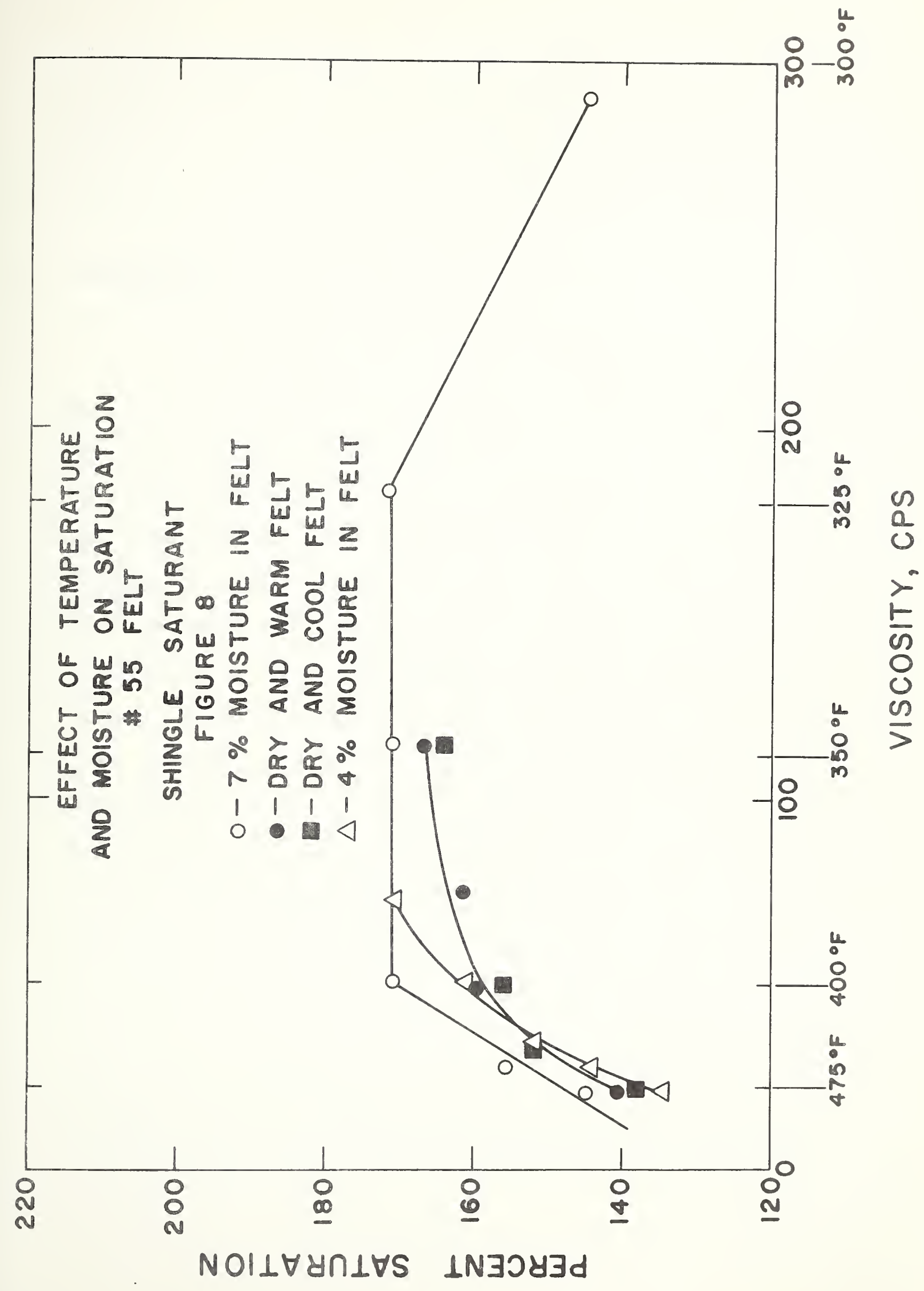




\section{.}


good penetration was found down to $300^{\circ} \mathrm{F}\left(150^{\circ} \mathrm{C}\right)$. At the higher temperatures, again, saturation was reduced rapidly with increasing temperature. In the range above $400^{\circ} \mathrm{F}\left(205^{\circ} \mathrm{C}\right)$ the felt with four percent molsture saturated like the dry felt; as the temperature was reduced below $400^{\circ} \mathrm{F}\left(205^{\circ} \mathrm{C}\right)$, it behaved more like the felt with seven percent moisture.

A few specimens of felt were exposed to high humidities and satuxated when they had moisture contents of 12 and 32 percent. At 12 percent molsture content, the saturation of the 非 27 felt was the same as with 7 percent moisture. However, the 非2 felts with 32 percent moisture absorbed 204 percent of saturant. This opening of the felt structure by moisture to permit improved saturation is accompanied by a serious lowering of the tensile strength of the molst felt and the introduction of a tremendous amount of foaming during the saturation process.

(c) Spacers on Press Rolls

One way of regulating the amount of free saturant carried on the sheet is to regulate the pressure applied on the press rolls. All of the results already discussed were obtained with the upper roll "floating". Attempts to increase the pressure resulted in decreased saturations. Attempts to decrease the pressure by elevating the bearings upon which the upper rolls rotated produced a condition that prevented the rolls from pulling the felt through themselves as they rotated; there was not sufficient "bite" to move the felt. A compromise was sought in the use of spacers directly on the upper roll consisting of aluminum tape five mils thick in multiple thicknesses. The edges 

of the felt were gripped between the bottom roll and the spacers on the top roll, leaving a free area over the felt to carry excess saturant. While this idea seemed good theoretically, in practice the results were very erratic. Wet areas remained after the soak-in period quite frequently and the results could not be used. All the results reported in Figures 9,10 and 11 are based on only the specimens that were in a "surface-dry" condition when removed from the soaking-in oven. The low temperature cutoffs in these figures represent the saturation temperatures below which only surface-wet specimens were obtained.

From the results shown in Figure 9, it is obvious that the use of spacers did not improve the saturation with shingle saturant under any conditions. The operating range was narrowed and only under the best conditions could satisfactory saturation be obtained with 30 - or 50-mil spacers.

Whe $\mathrm{n}$ the mixed saturant was used, as seen in Figure 10, the saturation was improved at the higher temperatures with both 30 - and 50mil spacers. However, again the spacers raised the lowest temperature at which surface-dry specimens could be produced.

Spacers thicker than $30 \mathrm{mils}$ were not investigated with the 非5 felt-roll saturant system. However, when 30-mil spacers were used, viscosities at which satisfactory saturation could be obtained were reduced further than with either the mixed or shingle saturants. These data are shown in Figure 11. The apparent anomaly of more low softening point saturant remaining in the felt at the lower viscosities may be explained on the basis that this viscosity is attained at lower 



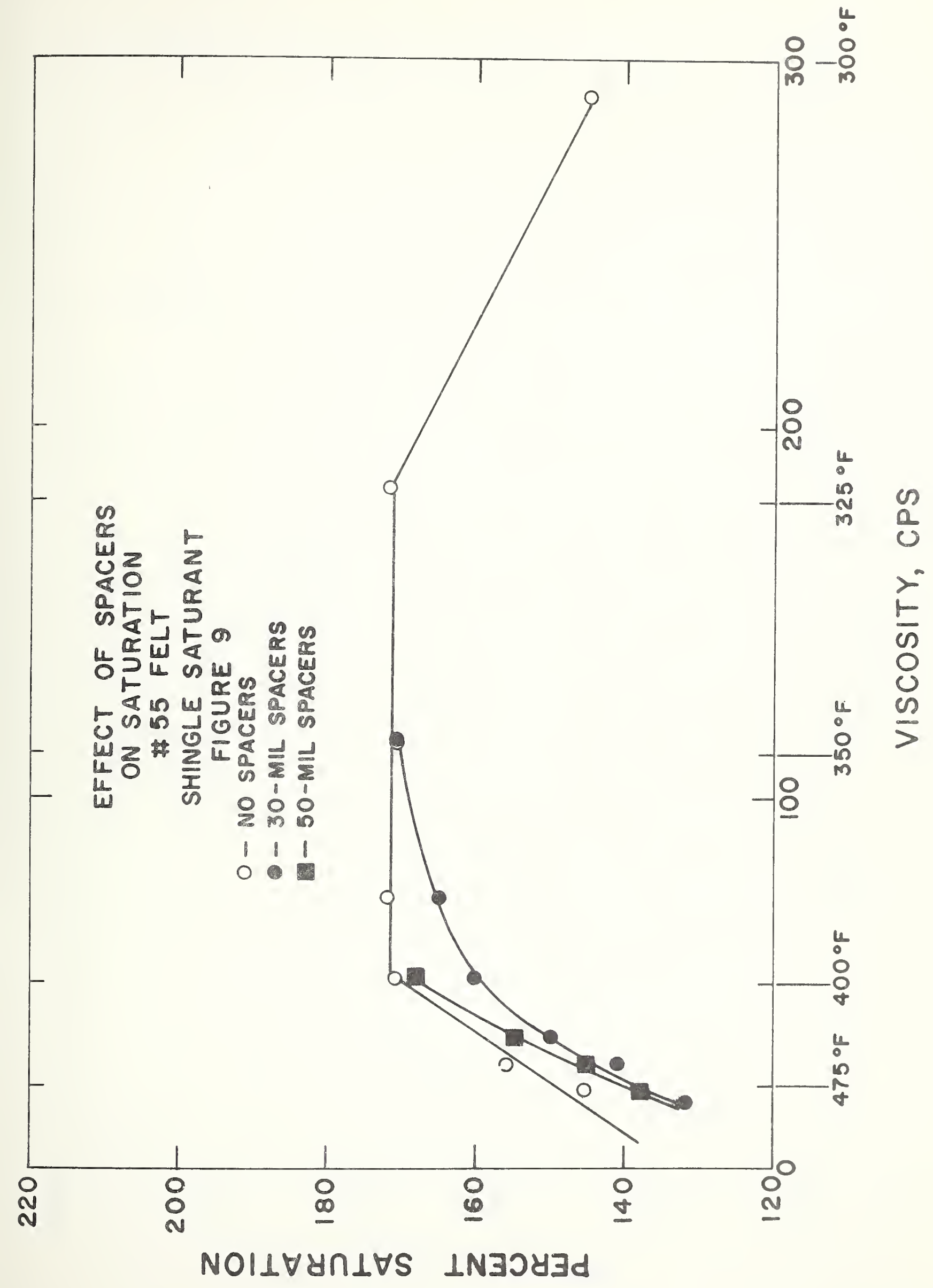





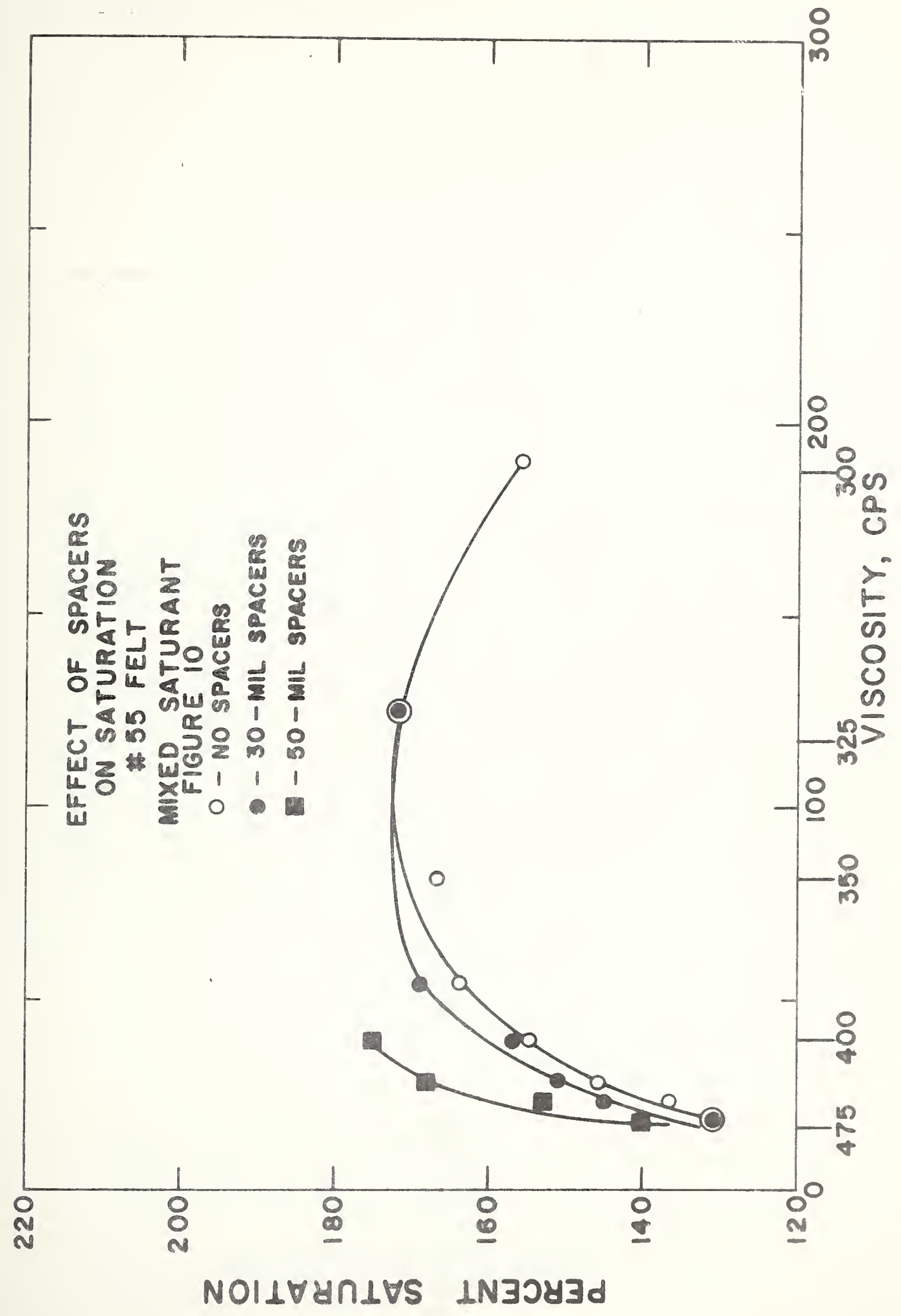




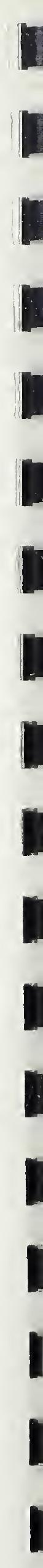




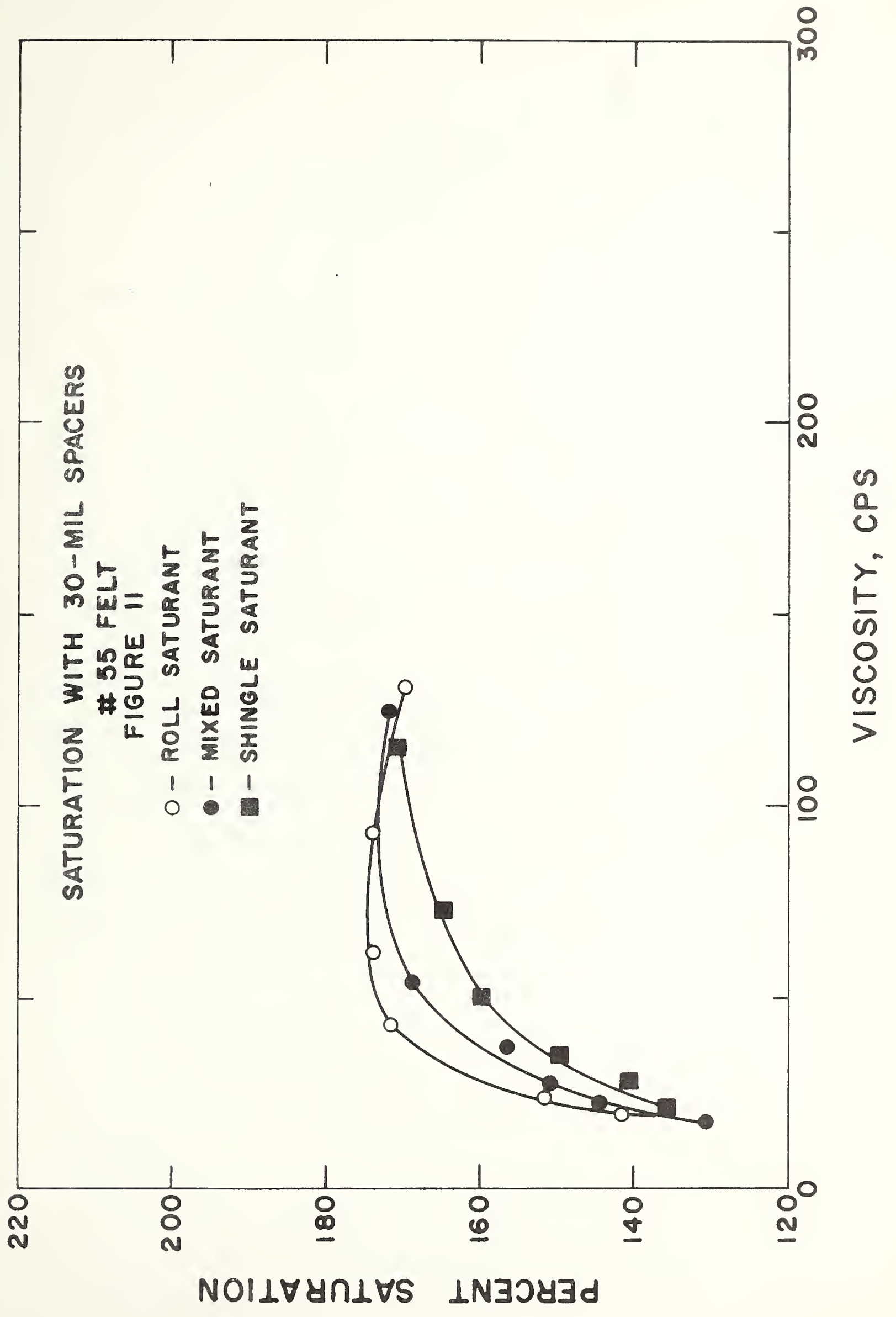




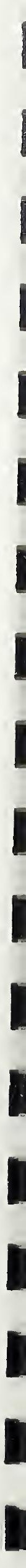


temperatures and the specific volume of the saturant is lower under these conditions (the density of the saturant is greater at a given viscosity as the softening point of the saturant is decreased). Another factor that undoubtedly helped the saturation was that the saturated felts were al1 exposed to a $350^{\circ} \mathrm{F}$ oven for the soak-in period. The softer saturant was the most fluid under these conditions and excess saturant could soak in better than the more viscous, higher-softening-point materials. Thus, surface conditions that provided "wet" saturated felts with the saturants normally employed with 非55 felt resulted in surface-dry felts when the roll saturant was used. Undoubtedly, the "soaking-in" temperature could be modified in practice to accommodate the higher viscosity saturants.

(d) Pressure

Possible ways of increasing the saturation of felts include the use of pressure or vacuum. The results of both of these techniques are presented in Figures 12 to 15.

For the system 非5 felt-shingle saturants in Figure 12, a small increase in pressure produced a significant increase in saturation. Progressively higher pressures improved the saturation further to 185 percent at $30 \mathrm{psig.} \mathrm{The} \mathrm{operating} \mathrm{ranges} \mathrm{of} \mathrm{temperature} \mathrm{remained}$ essentially the same at all pressures; uniformly high saturations were produced between $325^{\circ} \mathrm{F}\left(190^{\circ} \mathrm{C}\right)$ and $400^{\circ} \mathrm{F}\left(205^{\circ} \mathrm{C}\right)$ at viscosities of 190 to $50 \mathrm{cps}$, respectively. Pressures higher than $30 \mathrm{psig}$ were not investigated. 



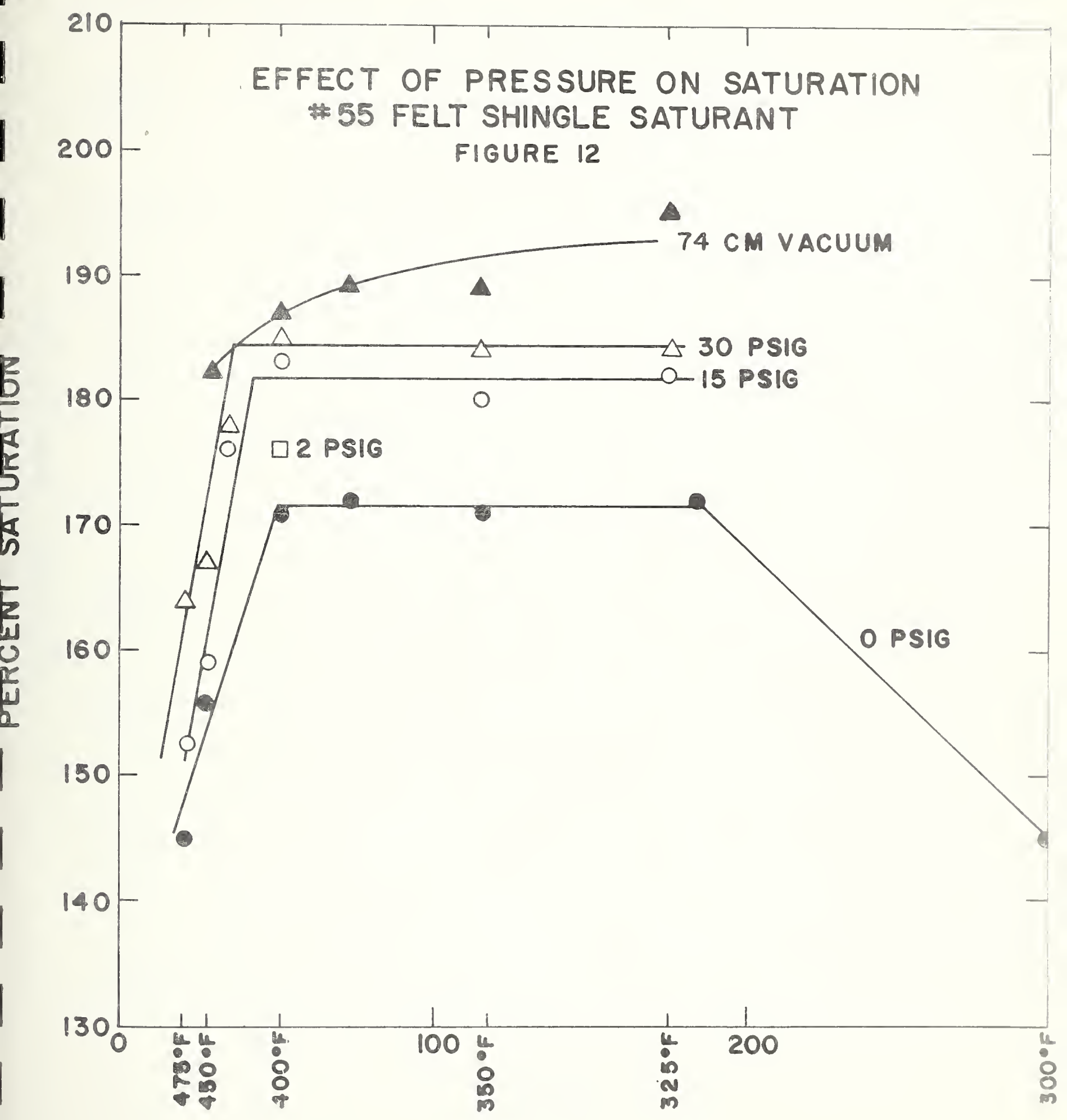

VISCOSITY, CPS 


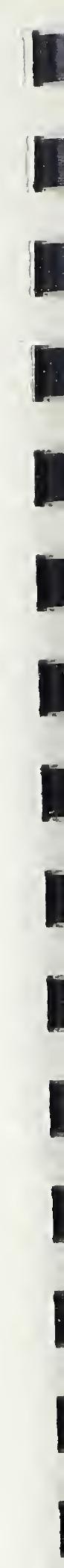




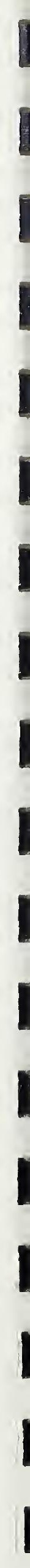




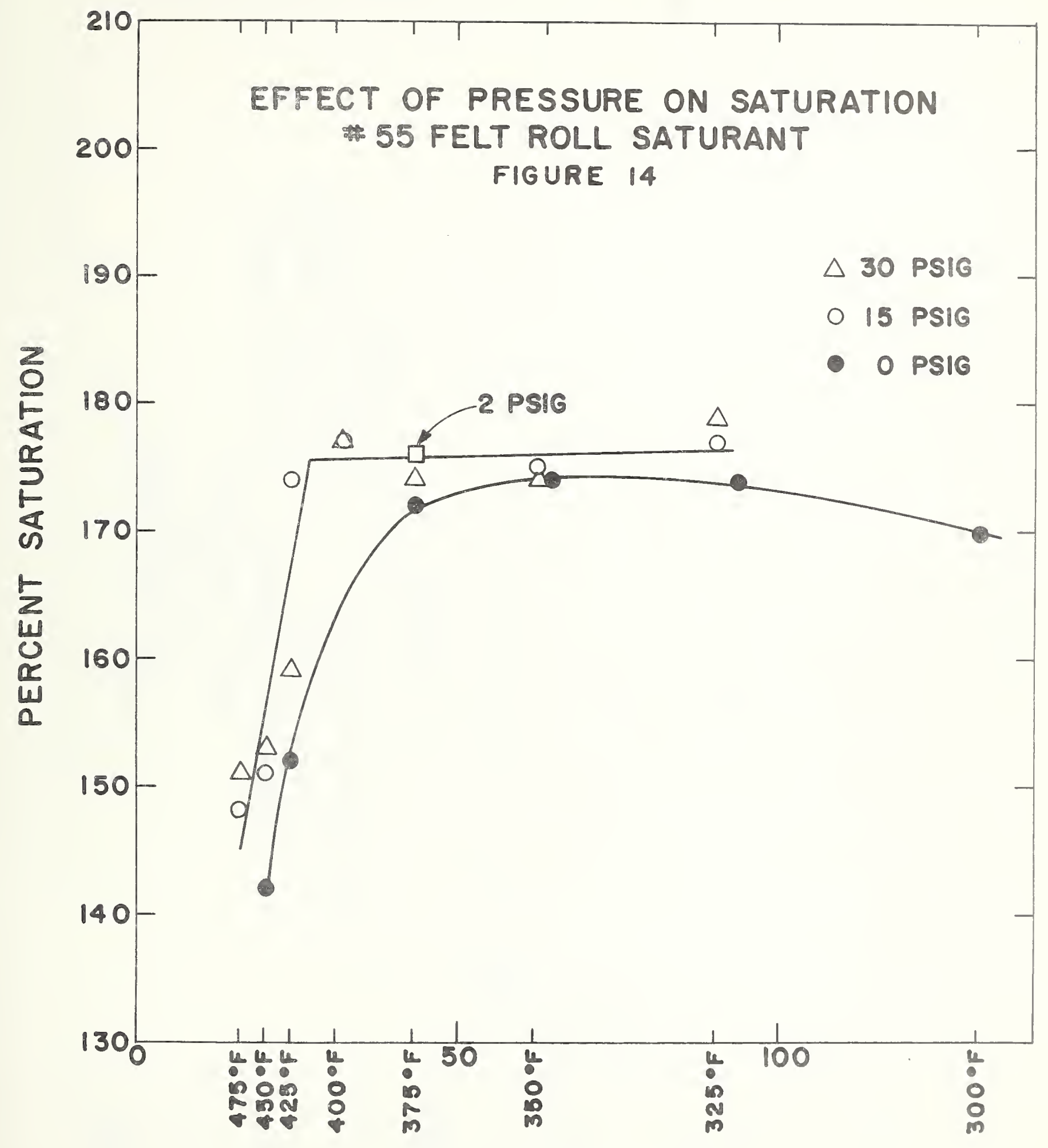

VISCOSITY, CPS 


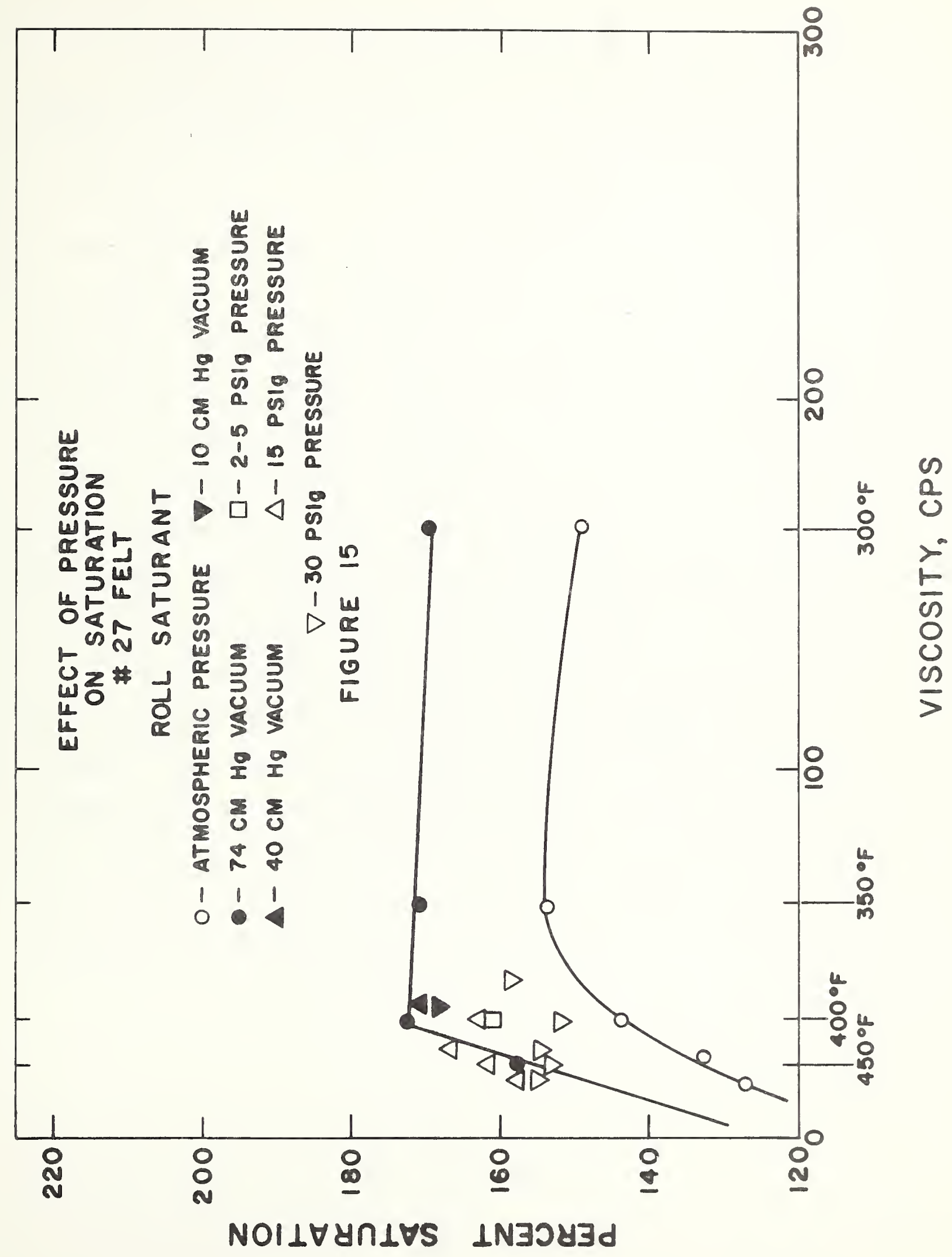


Reduction of the pressure in the saturator below atmospheric pressure permitted further increase in the saturation of the felts. At a vacuum of $74 \mathrm{~cm} \mathrm{Hg}$, the percent saturation was approximately 190, with top figures of 195.

The saturations under vacuum were extremely slow; whereas those under pressure were accomplished rapidly. Periods of 30 minutes were used for the specimens saturated under vacuum because bubbles continued to be released from the felt for 30 minutes. However, after the series was completed, it was found that times from five to thirty minutes produced essentially the same results. Periods below five minutes produced erratic results. The pressure results were all accomplished with one-minute submergence, followed by a rapid decrease to atmospheric pressure while the specimen was submerged.

An interesting consideration involving the use of pressure is the appreciable increase in saturation with small increases in pressure. In practice, pressure can be increased by merely making the saturant tank deeper and running the sheet close to the bottom of the tank. Pressure is attained at the rate of $0.43-0.45$ psi per foot of depth. Thus, the results obtained in Figure 12 at 2 psig could, presumably, be accomplished with saturant just over four feet deep. 
The beneficial effects produced by saturating with shingle saturant under pressure were also evident when the mixed saturant was used. As seen in Figure 13, 2 psig were sufficient to take a combination of saturant, felt and temperature that produced saturated felts failing to meet specifications and produce results comfortably above 170 percent. It is in this borderline type of situation that these small modifications in procedure can be most beneficial. Further increases in pressure to 15 psig produced additional improvement in saturation. However, beyond $15 \mathrm{psig}$, no further improvement was noted. As a matter of fact, 30 psig produced saturations essentially the same as 15 psig.

As might be expected, saturation with the most fluid saturant used, the roll saturant, was not greatly influenced by pressure. The data in Figure 14 reveal that all elevated pressures produced essentially the same degree of saturation between $325^{\circ}\left(190^{\circ} \mathrm{C}\right)$ and $400^{\circ} \mathrm{F}\left(205^{\circ} \mathrm{C}\right)$ as did atmospheric pressure saturation. However, the range over which the saturation of about 174 percent was attained was extended about $50^{\circ} \mathrm{F}$ to $425^{\circ} \mathrm{F}$ at super-atmospheric pressures. Thus, even when roll saturant was used, some improvement could be obtained by the use of pressure.

Commercially no difficulty is encountered in saturating the 非7 felt. A very soft saturant is used to keep the saturated felt pliable in cool weather and compatible with mopping-grade asphalts. The saturation is kept Iow, 140 percent minimum, to prevent the adjacent layers in the rolls from adhering to each other. However, it is known that greater saturations improve the protection of the fibers. 
Therefore, the effect of vacuum and pressure on the saturation of 非 7 felt with roll saturant was studied. The results are reported in Figure 15.

Elevated pressures and vacuums down to about one-half atmosphere greatly restricted the temperature range in which surface-dry, saturated felts could be obtained to $390^{\circ} \mathrm{F}\left(200^{\circ} \mathrm{C}\right)$ or higher. In this range, improved saturations were always obtained. When $74 \mathrm{~cm} \mathrm{Hg}$ of vacuum was used, satisfactory and maximum saturation could be obtained over the complete temperature range from $300^{\circ} \mathrm{F}\left(150^{\circ} \mathrm{C}\right)$ to $400^{\circ} \mathrm{F}\left(205^{\circ} \mathrm{C}\right)$. The percent saturation began to decrease, however, as the saturant temperature was raised above $400^{\circ} \mathrm{F}\left(205^{\circ} \mathrm{C}\right)$. The 非 27 felt, thus, could be saturated with 170 percent saturant and still be surface dry by the use of vacuum. Elevated pressures could be used to produce saturations up to 165 percent if the saturant temperature was closely controlled in the higher temperature range.

\section{(e) Moisture Absorption}

The purpose of saturating felts with asphalt is to protect them and make them more resistant to attack by the elements of the weather. Dry felts are particularly vulnerable to moisture in both Iiquid and vapor form. The results in Figure 6 show that dry felts sorb up to 9 percent moisture when exposed to relative humidities of 75 percent for less than a day. This equilibrium moisture will be higher if the storage temperature is lower and lower if it is higher than $79^{\circ} \mathrm{F}$. It has been reported that large dimensional changes occur in felts with moisture changes and progressively larger shrinkages result (5). 

To determine how well saturation protects felts, a series of

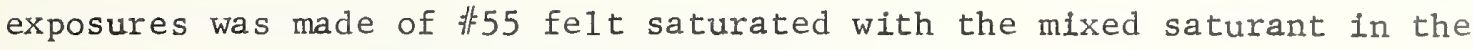
range of 64 to 185 percent to relative humidities of 30,50 , and 75 percent. It had been planned to continue determinations at all three relative humidities for 500 hours, but the exposure conditions drifted out of the control ranges after 200 hours at 30 percent relative humidity and 150 hours at 75 percent relative humidity. The figures in the inserts represent the last set of readings under controlled conditions.

The specific data for the 非55 felts saturated with the mixed saturant are presented in Figures 16, 17 and 18 for relative humidities of 30,50 , and 75 percent, respectively. Similarly, data for the moisture absorption of the 非 27 felts saturated with roll saturant and exposed at $73^{\circ} \mathrm{F}$ and 50 percent relative humidity are in Figure 19.

At all relative humidities moisture absorption proceeded rapidly at first and then at progressively lower rates until some constant moisture content was attained. The rate of absorption, rate of attaining "equilibrlum" and "equilibrium" molsture content decreased as the saturation of the felt was increased. The final moisture content decreased approximately linearly with the log of the percent saturation. Similarly, for any particular saturation, the "equilibrium" moisture content increased with the relative humidity to which the felts were exposed. 



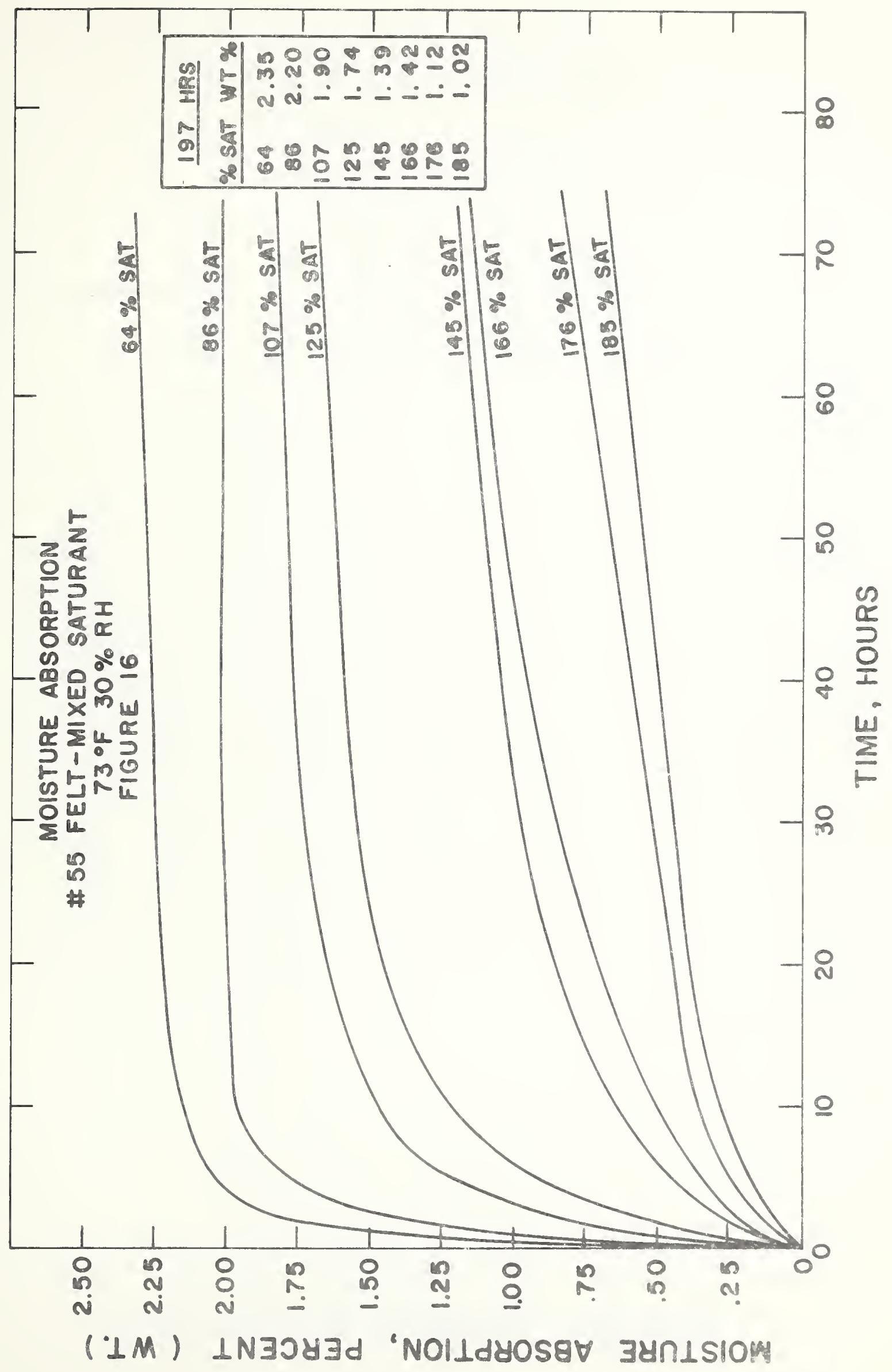





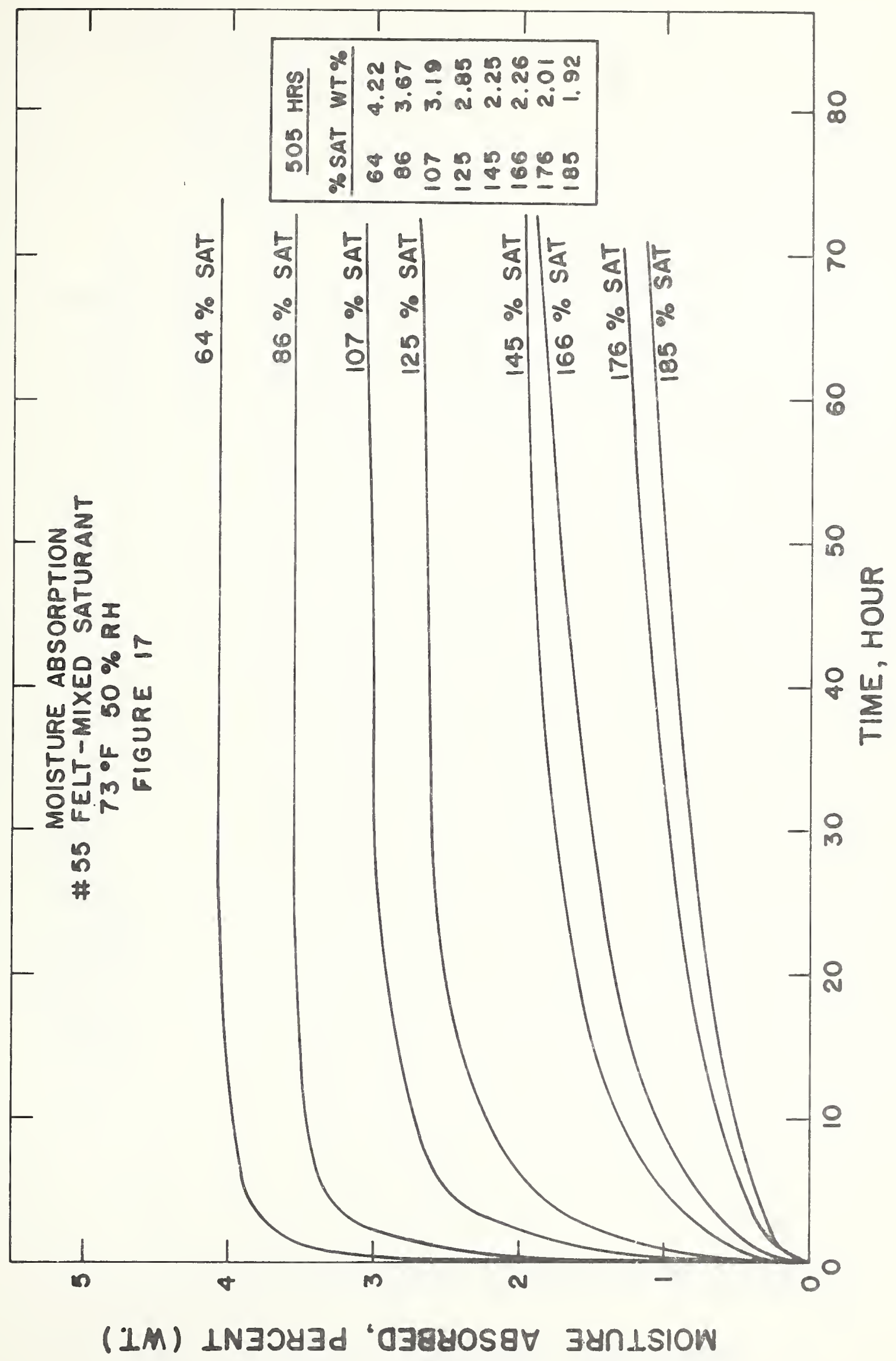





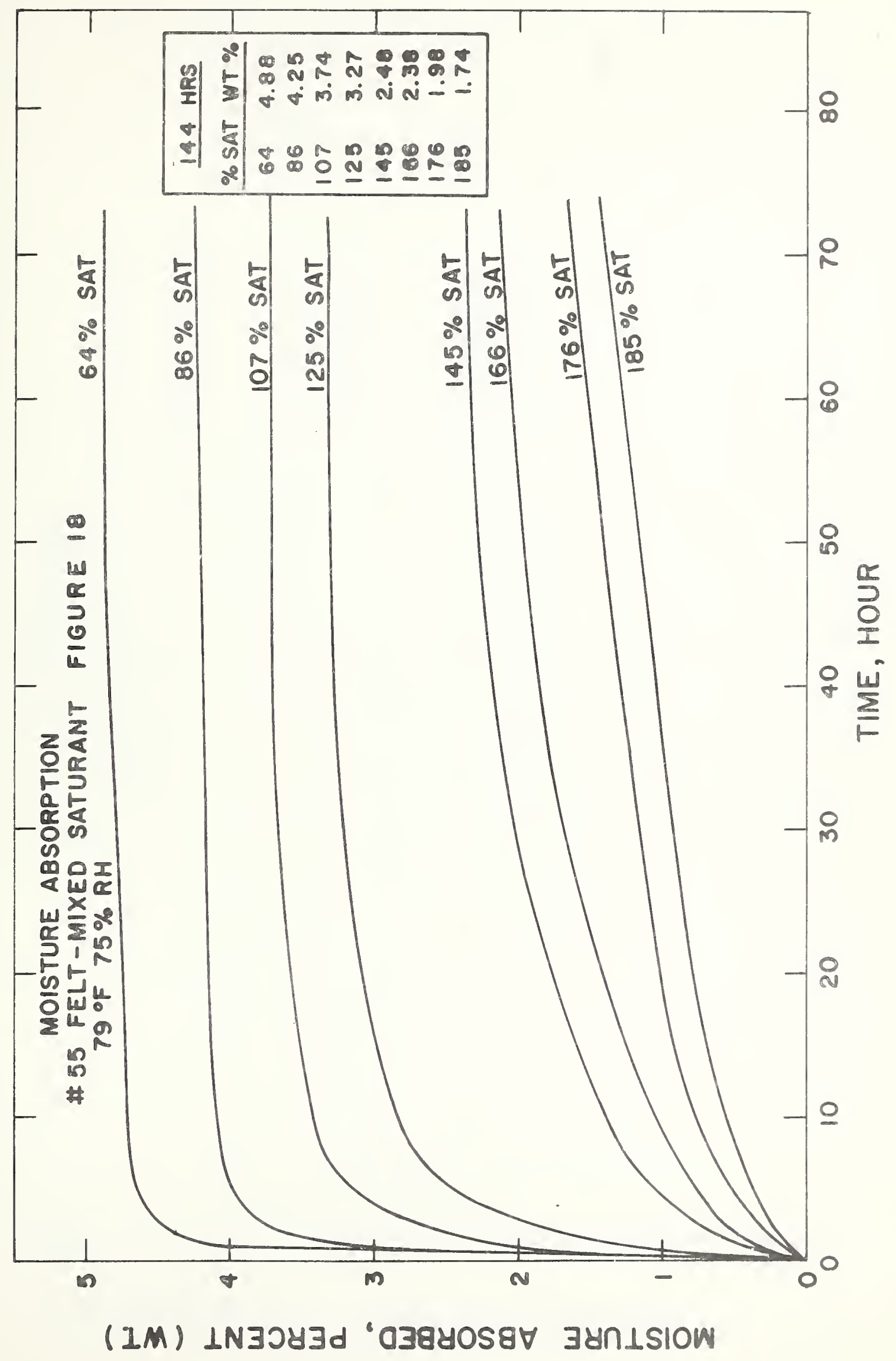





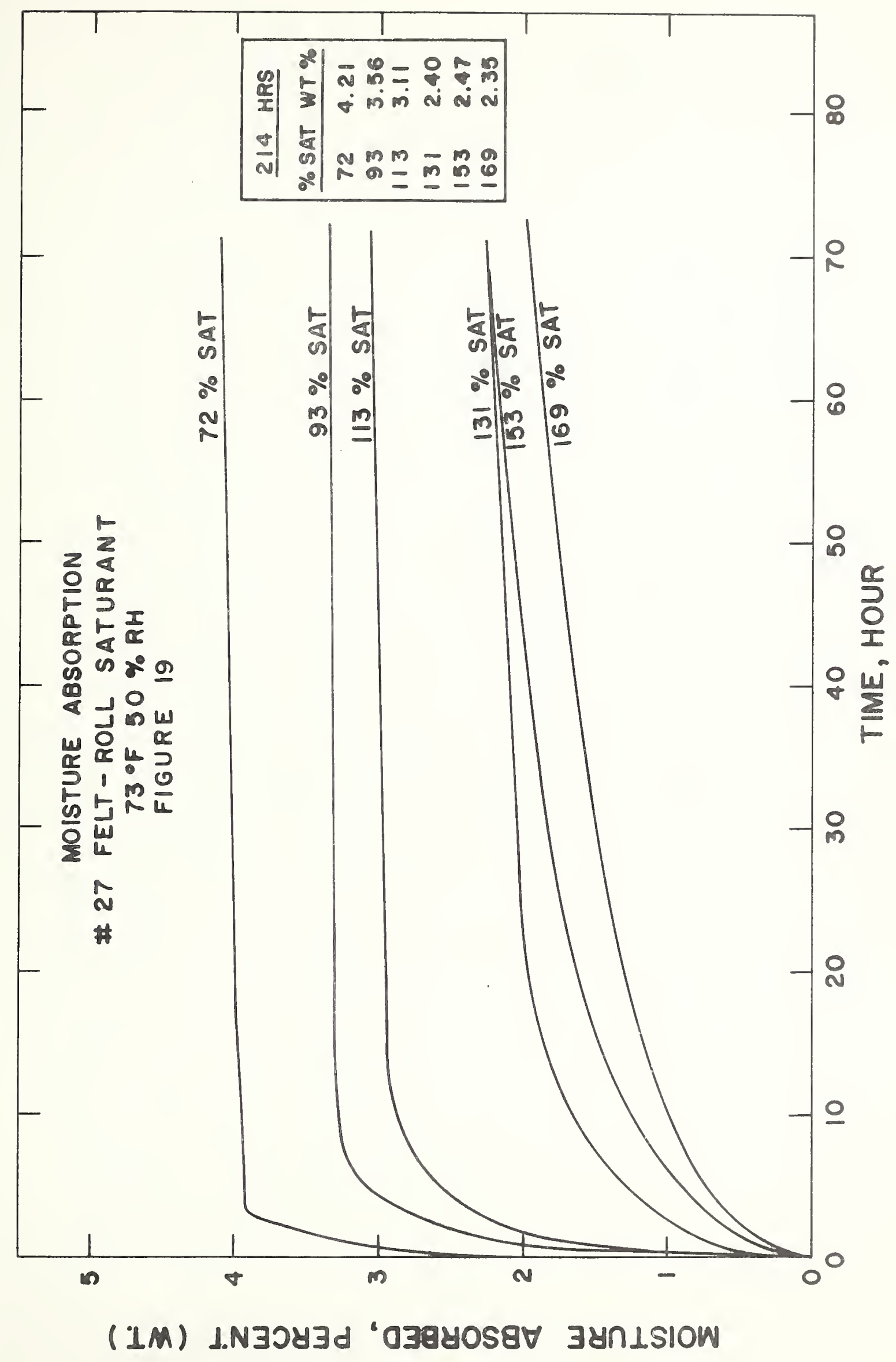



It is significant to note that even a small degree of saturation, such as about 60 percent, reduced both the rate of moisture absorption and final moisture content of the felts appreciably. Data from Figures 6 and 16 show that at 30 percent relative humidity the final moisture content is reduced by 50 percent at this low saturation, and the time to attain it is increased appreciably. At specification saturations and higher, the final moisture content is reduced by 75 percent and the time to attain it increased much more. At the higher humidities, the improvements are more pronounced.

On the negative side of the picture, however, is the inescapable fact that even the most highly saturated felts in this study sorbed moisture to a degree. Front and back coating shingles thus offer the isolation fully saturated felts need from moist atmospheres.

When considering the 非2 7 saturated felts, this vulnerability to moisture sorption is very significant. They are normally saturated to above 140 percent and, thus, may sorb up to 2.5 percent moisture at 50 percent relative humidity and $73^{\circ} \mathrm{F}$. This sorption can occur in storage or on the roof if the roof is not completed in one session. The exposure of an unsurfaced roof over night, when the temperature drops and the relative humidity increases, could lead to much higher moisture sorption. As the roof is finished, the hot asphalt application must vaporize this moisture. Asphalt cooling and some frothing and foaming result. This moisture sorption if accomplished non-uniformly throughout a roll of felt could lead to temporary or permanent distortions of the felt. 
If conditions are made more severe, and the felt is submerged in liquid water for periods in excess of one hour, the quantity of water sorbed increases rapidly. Felts meeting ASTM specifications will sorb about 10 percent water in a week. The data in Figure 20 are for the 非55 saturated felts. While the 非7 felts were not evaluated, it is anticipated that comparable results would be attained in shorter periods of time. These data further emphasize the necessity for protecting saturated felts by impermeable surface coatings as rapidly as possible.

(f) Air Permeability

Air permeability of saturated felts decreases rapidly as the saturation is increased. With the densometer normally used for dry felts, the results become rather erratic and the times become long for saturations higher than 125 percent. It is interesting to note that both the 非7 and 非5 felts fell on the same curve in Figure 21. (In order to obtain the data for this correlation, the actual areas through which the air permeated were extracted to obtain the saturations. Each point represents an individual determination. The local variations in any piece of saturated felt were too large to permit the use of average values).

For applications in which felt is used as a wind barrier, but not as a vapor barrier, highly saturated, but uncoated, felts should be recommended. If a vapor barrier is desirable, saturated and coated felt should be used. 



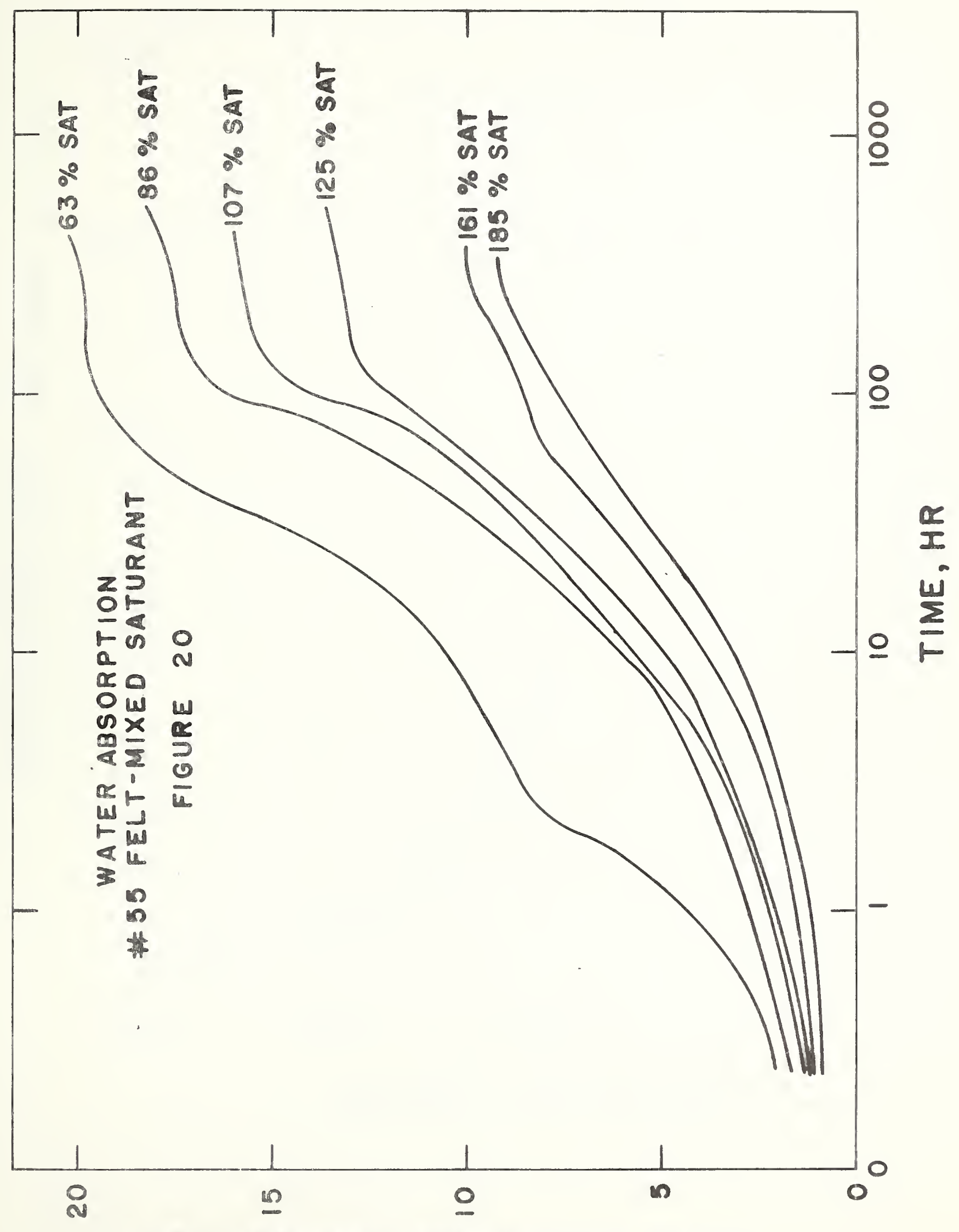

( LM) LN3DYJd 'NOILdYOSgV $\forall \exists \perp \forall M$ 



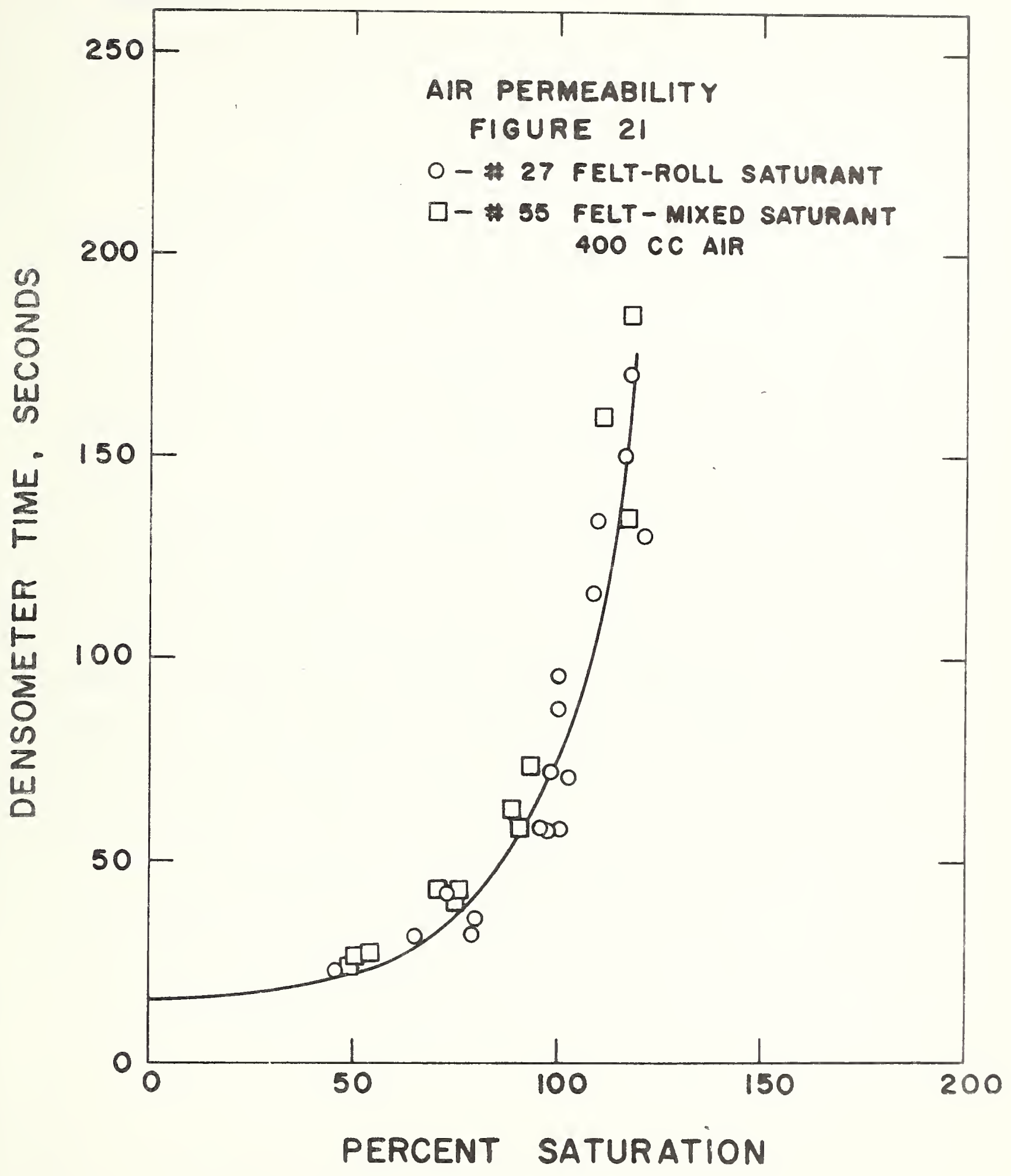





\section{CONCLUSIONS}

Saturating organic felts under controlled conditions in the laboratory has demonstrated that the efficiency of saturation varies with a large number of parametars, including time of immersion, temperature (or viscosity) of the saturant, pressure on the press rolls and pressure in the saturator. However, even under the most favorable conditions, only 82 percent of the theoretically possible saturation was attained. This Figure, 25 percent over the specification minimum, was equal to the asphalt saturating number as determined by the burette method; thus, an efficiency of 100 percent of the burette asphalt saturating number was attained.

The technical conclusions obtained from this study may be summarized as follows:

(1) At $400^{\circ} \mathrm{F}\left(205^{\circ} \mathrm{C}\right)$ with the saturants normally used, it was immaterial whether the 1327 felt was saturated from either one or both sides if more than 15 seconds of submersion time was used. The 非5 felt required a minimum of one and a half minutes of complete submersion to meet minimum specification requirements.

(2) Felts were saturated to a greater extent and more easily if they contained a small quantity of moisture. Moisture seemed to "open up" the felt. Large moisture contents permitted still greater saturation, but produced foaming and cooled the saturant excessively. 

(3) Felts saturated under normal conditions best in the viscosity range of 50 to $150 \mathrm{cps}$. At higher viscosities the penetration was hindered; at lower viscosities, the sheet could not "carry" sufficient saturant to meet specifications.

(4) Spacers on the press rolls increased the quantity of saturant carried on the sheet, but the viscosity range in which surface-dry saturateu felts could be produced was greatly shortened. The beneflcial effects were more noticeable with the softer saturants.

(5) Small increments of pressure in the saturator produced marked increases in saturation, especially with the harder saturants. Higher pressures produced further improvements in saturation with the shingle saturant, but not with the softer saturant.

(6) Vacuum saturation produced the highest saturations.

(7) Rate of moisture and liquid water sorption of saturated felt decreased with increasing saturation. A large fraction of the total sorption occurred in the first few hours of exposure.

(8) Air permeability decreased rapidly with increasing saturation. 



\section{REFERENCES}

(1) Abraham, H., Asphalts and Allied Substances, Fifth Edition, I, 743-747, D. Van Nostrand \& Co., Inc., New York (1945).

(2) Krchma, I. C., Asphalts for Process Industries, Chapter in Bituminous Materials, II, 593, Interscience Publishers, Inc. (1965).

(3) Casey, J. P., Pulp and Paper Chemfstry and Technology, I, 81, Interscience Publishers, Inc., (1960).

(4) Ott, E., H. M. Spurlin and M. W. Grafflin, Cellulose and Cellulose Derivatives, 5, Part 1, Intersclence Publishers, Inc., New York (1955) .

(5) Martin, K. G., Changes in Bituminous Roofing Felts Associated with Changes in Moisture Content, Div. of Bldg. Res. Tech. Paper No. 8, C.S.I.R.O., Australia (1959). 



\section{ACKNOWLEDGMENT}

The author wishes to thank Messrs. J. C. Weeks and T. R. Davis for their assistance in the experimental work. 

(i) 